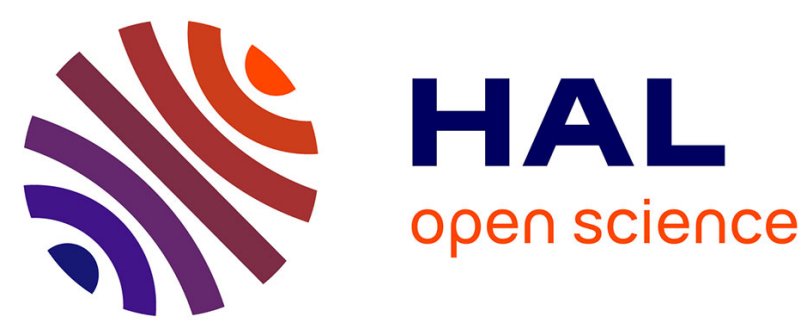

\title{
Promises and limitations of nanoparticles in the era of cell therapy: Example with CD19-targeting chimeric antigen receptor (CAR)-modified $T$ cells
}

Helene Jakobczyk, Flavien Sciortino, Soizic Chevance, Fabienne Gauffre, Marie-Bérengère Troadec

\section{To cite this version:}

Helene Jakobczyk, Flavien Sciortino, Soizic Chevance, Fabienne Gauffre, Marie-Bérengère Troadec. Promises and limitations of nanoparticles in the era of cell therapy: Example with CD19-targeting chimeric antigen receptor (CAR)-modified T cells. International Journal of Pharmaceutics, 2017, 532 (2), pp.813-824. 10.1016/j.ijpharm.2017.07.075 . hal-01617055

HAL Id: hal-01617055

https://hal-univ-rennes1.archives-ouvertes.fr/hal-01617055

Submitted on 24 Oct 2017

HAL is a multi-disciplinary open access archive for the deposit and dissemination of scientific research documents, whether they are published or not. The documents may come from teaching and research institutions in France or abroad, or from public or private research centers.
L'archive ouverte pluridisciplinaire HAL, est destinée au dépôt et à la diffusion de documents scientifiques de niveau recherche, publiés ou non, émanant des établissements d'enseignement et de recherche français ou étrangers, des laboratoires publics ou privés. 
1 TITLE:

2 PROMISES AND LIMITATIONS OF NANOPARTICLES IN THE ERA OF CELL

3 THERAPY: EXAMPLE WITH CD19-TARGETING CHIMERIC ANTIGEN

4 RECEPTOR (CAR)-MODIFIED T CELLS

5

6 Authors:

7 Hélène Jakobczyk ${ }^{a, b}$, Flavien Sciortino $^{c}$, Soizic Chevance ${ }^{c}$, Fabienne Gauffre ${ }^{c}$,

8 Marie-Bérengère Troadec ${ }^{a, b}$

9

Affiliations :

11 a Institut de Génétique et Développement de Rennes, UMR 6290 CNRS, Université

12 de Rennes 1, Rennes, France

13 b SFR Biosit UMS CNRS 3480/US INSERM 018, Rennes, France

$14{ }^{c}$ Institut des Sciences Chimiques de Rennes, UMR 6226 CNRS, Université de

15 Rennes 1, Rennes, France

16

17

18

corresponding author :

19 Marie-Bérengère Troadec

20 marie-berengere.troadec@univ-rennes1.fr

21

22 


\section{ABSTRACT}

A number of nanoparticles has been developed by chemists for biomedical applications to meet imaging and targeting needs. In parallel, adoptive T therapy with chimeric antigen receptor engineered T cells (CAR T cells) has recently held great promise in B-cell malignancy treatments thanks to the development of anti-CD19 CAR T cells. Indeed, CD19 is a reliable B cell marker and a validated target protein for therapy. In this perspective article, we propose to discuss the advantages, limits and challenges of nanoparticles and CAR T cells, focusing on CD19 targeting objects: anti-CD19 nanoparticles and anti-CD19 CAR T cells, because those genetically-modified cells are the most widely developed in clinical setting. In the first part, we will introduce B cell malignancies and the CD19 surface marker. Then we will present the positioning of nanomedicine in the topic of B cell malignancy, before exposing CAR T technology. Finally, we will discuss the complementary approaches between nanoparticles and CAR T cells.

KEY WORDS

43

44 Nanoparticles, CD19, chimeric antigen receptor, T cell, B cell, cell therapy 
1 CD19, A B CELL RESTRICTED SURFACE PROTEIN AND A RELIABLE MARKER OF B CELL

1.3.2 Internalization of CD19 after binding to anti-CD19 antibody

1.3.3 Cells that express CD19

1.3.4 CD19 as a target for therapy

2.1 NON TARGETING NANOPARTICLES FOR THERAPY AND IMAGING OF B CELL MALIGNANCY 10

\subsection{CD19-TARGETING NANOPARTICLES}

2.2.1 Imaging with anti-CD19 nanoparticles

2.2.2 Therapy with anti-CD19 nanoparticles 4 PERSPECTIVES: HOW NANOPARTICLES AND CAR T CELL THERAPY COULD BE COMPLEMENTARY? 
INTRODUCTION

82 A hematological malignant cell is defined as a hematopoietic cell blocked at an early stage of differentiation and undergoing an uncontrolled clonal proliferation. So far, tremendous improvement in cancer treatment has been obtained thanks to the identification of therapeutic drugs, better molecular understanding of the onset and progression of malignancy, more sensitive detection of tumor cells, more effective follow-up of the disease, better management of adverse effects, optimization of protocol design... Many challenges are still to be undertaken. From the time a patient arrives to be diagnosed to the moment he is cured, physicians and medical staff encounter at least the following issues: the early identification of the tumor, the imaging of malignant cells (where are localized the malignant cells? Is that the primary tumor or a metastasis?), the delivery of therapeutic drugs and avoidance of adverse effects on non-malignant cells (sometimes minimizing the risk of generation of a secondary cancer), and finally the identification of residual cells that could ultimately be at the origin of refractory cancer or relapse.

The chimeric antigen receptor (CAR) T cell therapy is a revolutionary approach of targeted immunotherapy to treat cancer. In CAR T cell therapy, the therapeutic effector is a genetically modified cell. CAR T cell therapy may not yet be poised to overtake chemotherapy as the standard of care, however, it is looking as a promising

101 treatment for certain patients with no other feasible therapeutic option, such as in 102 relapsed or refractory leukemia. An alternative research approach for the treatment 103 of cancer is offered by nanoparticles, which have been proposed as carriers for drug 104 encapsulation in the 60's. Since then, a variety of organic and inorganic nanoparticles, with sizes ranging from circa $5 \mathrm{~nm}$ to $200 \mathrm{~nm}$, have been designed for 
a wide range of applications including targeted drug delivery and imaging, thus boosting the activity of nanomedicine, with some remarkable results particularly in the field of cancer diagnosis and therapy.

110 In this perspective article, we will propose to discuss the challenges of nanoparticles

111 and CAR T cells in the context of hematological malignancies. We will focus on CD19

112 targeting objects: anti-CD19 nanoparticles and anti-CD19 CAR T cells because those 113 genetically modified cells are the most widely developed in clinical setting.

114 In the first part, we will introduce B cell malignancies and their CD19 surface marker, 115 then we will present the positioning of nanomedicine in the topic of B cell malignancy, 116 before exposing CAR T technology. Finally, we will discuss the complementary 117 approaches between nanoparticles and CAR T cells. From the biological point of 118 view, anti-CD19-grafted nanoparticles and anti-CD19 CAR T cells target the same B 119 cell lineage. From the therapeutic perspective, nanoparticles and CAR T cells 120 approaches share common objectives: the optimization of therapeutic effect on target 121 cells and the minimization of adverse effects. However, the mechanisms of action are 122 different (see the graphical abstract). It seems reasonable to conceive that 123 nanoparticles could play a significant role for the potentiation of, and the cooperation 124 with CAR T cell therapy in the future. 


\subsection{THE FUNCTIONS OF B LYMPHOCYTES}

130 B cells (also named B lymphocytes) achieve multiple functions that explain their

131 central role in the immune system (Figure 1). Their main role is the production of

132 antibodies to identify and neutralize pathogens. The binding of a B lymphocyte to an

133 antigen triggers an initial step of multiplication and differentiation either into plasma

134 cell which secretes antibodies or into memory B cell. Besides their role in humoral

135 immunity, B cells are involved in cytokine production (e.g. IFNy, IL6, IL10), antigen

136 presentation to $\mathrm{T}$ cells, wound healing, cytokine balance for the differentiation

137 between T lymphocytes (Th1 and Th2 cells), but also in the transplant rejection

138 (review in (LeBien and Tedder, 2008)).

139 B cells undergo differentiation, from hematopoietic stem cells to plasma cells or 140 memory B cells, through a series of stages characterized by the orderly 141 rearrangement and expression of immunoglobulins genes including CD19 (Figure 1).

142 The development of $B$ cells is also distinguished into different stages by the 143 sequential expression of different transcription factors that induce immunoglobulin 144 gene recombination and the expression of specific surface phenotypes. The onset of 145 B cell lineage occurs in the bone marrow until the immature stage, then mature B 146 cells move into the periphery (i.e. out of the bone marrow) (Zhu and Emerson, 2002).

\subsection{B CELL MALIGNANCIES}

149 B cell malignancies are hematological cancer characterized by uncontrolled 150 proliferation of B lymphocytes blocked along their differentiation process. B cell 151 malignancies are classified as leukemia (which develops in the bone marrow and 152 disseminates into the body), lymphoma (a cancer of the lymphatic system 153 characterized by the development of a cancer cells in lymph nodes) and myeloma 
154 (cancer of mature B lymphocytes in the bone marrow) (review in (Wang et al., 2012)).

155 B cell malignancies represent $4 \%$ of all cancers in adults and $40 \%$ of all cancers in 156 children. The clinical outcomes of these cancers under standard chemotherapy 157 depend on the type of B cell malignancies. For instance, children with B-Acute 158 Lymphoblastic Leukemia (ALL) have an overall good prognosis, but some of them 159 are refractory to chemotherapy or develop multiple relapses and have a poor 160 prognosis (review in (Park et al., 2016)). Relapsed or refractory B cell ALL in adults

161 are associated with a poor prognosis (review in (Geyer and Brentjens, 2016)).

\subsection{THE SURFACE PROTEIN CD19: A VALIDATED TARGET PROTEIN FOR THERAPY}

\section{CD19 structure and function}

$165 \mathrm{CD} 19$ is a $95 \mathrm{kDa}$ transmembrane glycoprotein of the immunoglobulin superfamily composed of an extracellular domain, a single transmembrane domain, and a cytoplasmic domain (Stamenkovic and Seed, 1988). CD19 belongs to the CD19 complex on the surface of B cells with CD21 and CD81 proteins (Figure 2). CD19

169 activation induces two downstream pathways. The first cascade of activation is 170 dependent on the B Cell Receptor (BCR). The BCR is composed of a membrane 171 immunoglobulin and a signaling subunit composed of a heterodimer of 172 immunoglobulin alpha and beta. The BCR plays a role as antigen receptor and CD19 173 is a co-receptor for BCR signal transduction (review in (Wang et al., 2012)). The 174 second pathway depending on CD19 is independent of the BCR: the CD19 complex

175 is able to bind activated complement fragment C3d and modulates BCR signaling 176 (review in (Wang et al., 2012)). 
179 CD19 proteins on the surface of each B lineage leukemia/lymphoma cells are rapidly 180 internalized upon ligation with anti-CD19 antibodies or immunoconjugates (Uckun et 181 al., 1988; Yan et al., 2005), and are ultimately taken up by lysosomes (Carter, 2006 ; 182 Gerber et al., 2009; Hong et al., 2015).

\subsubsection{Cells that express CD19}

185 CD19 is a B cell-specific protein expressed early in B cell ontogeny (Stamenkovic and Seed, 1988) (Figure 1). CD19 transcripts are restricted to members of the B cell

187 lineage and are not expressed in other hematological lineages including normal 188 myeloid, erythroid, megakaryocytic, or multilineage bone marrow progenitor cells 189 (Uckun et al., 1988). CD19 protein is found on the surface of B cells from the proB 190 cell stage until plasma cell differentiation of the B lineage (Tedder et al., 1994). 191 Several hundred thousand CD19 proteins can be found on the surface of each B192 lineage leukemia/lymphoma (Uckun et al., 1988)(review in (Li et al., 2017)). All 193 resting B cells display CD19 antigens, and CD19 expression persists upon activation, 194 but is lost upon further differentiation to immunoglobulin-secreting plasma cells 195 (Stamenkovic and Seed, 1988). CD19 is also more abundant in pre-B cell lines and 196 less abundant in plasmacytomas (Stamenkovic and Seed, 1988). Almost all early B 197 cell malignancies show CD19 expression at normal to high levels: $80 \%$ of ALL, $88 \%$ 198 of B cell lymphomas and $100 \%$ of B cell leukemias (review in (Wang et al., 2012)). 199 However its expression decreases in myeloma cases (review in (Wang et al., 2012)). 
202 Twenty years ago, CD19 was already proposed as a « suitable target for 203 immunotoxin-mediated treatment of aggressive forms of B cell lymphomas and 204 leukemia that responds poorly to conventional chemotherapy» (Uckun et al., 1988). 205 Currently, CD19 antibody-based therapy has become reality to treat B cells 206 malignancy. In the 2010's, various strategies harnessing the potential of targeting B 207 cells restricted to CD19 antigen were in development: antibody-drug conjugate, Fc208 engineered human CD19 antibody with antibody-dependent cell-mediated 209 cytotoxicity, chimeric antigen receptor, etc. (Hammer, 2012). The most advanced 210 anti-CD19 therapy is the Blinatumomab (BLINCYTOß, Amgen) (review in (Hammer, 211 2012)) (Goebeler and Bargou, 2016), a bispecific CD19-directed CD3 T cell engager 212 (BiTE) antibody construct. Blinatumomab binds specifically to CD19 expressed on 213 the surface of cells of B-lineage origin, and to CD3 expressed on the surface of T 214 cells. It brings both cells in contact so that the activated T cells can kill the B cells. 215 Blinatumomab is approved by the US Food-and-Drug-Administration (FDA) and the 216 European Commission (EC) for the treatment of Philadelphia chromosome-negative 217 relapsed or refractory B-ALL, in adults (USA and EC) as well as in children (USA 218 only). Additionally, anti-CD19 antibodies are also in development for 219 radioimmunotherapy in preclinical studies. ${ }^{131}$ I-labeled anti-CD19 antibody has been 220 largely explored for conventional ${ }^{131}$ I radioimmunotherapy because antigen rapidly 221 internalizes upon binding of antibody - resulting in catabolism and release of ${ }^{131}$ I 222 (Scheinberg and Strand, 1983). Moreover, ${ }^{90}$ Y-particle-labeled anti-CD19 antibody 223 has shown an efficacy comparable to ${ }^{90} \mathrm{Y}$-labeled anti-CD20 antibody in 224 radioimmunotherapy of mice with xenografts of human B lymphoma cell lines (Ma et 225 al., 2002). 


\section{NANOMEDICINE IN THE TOPIC OF B CELL MALIGNANCY}

A number of nanoparticles has been proposed by chemists for cancer diagnostics

230 and therapeutics, as summarized Table 1. Organic nanoparticles, such as

231 liposomes, oil-in-water emulsions or polymeric particles, are mainly used as carriers, 232 whereas nanoparticles, such as superparamagnetic iron oxide nanocrystals or 233 quantum dots, show interesting intrinsic properties for imaging and therapy.

\subsection{NON TARGETING NANOPARTICLES FOR THERAPY AND IMAGING OF B CELL}

237 Some anticancer encapsulation nanosystems have made their way to the market

238 (Pattni et al., 2015). Liposomal formulations encapsulating drugs, such as 239 doxorubicin, are commercialized under the name of Myocet, Doxil, Lipodox and 240 Caelyx. Related to hematological malignancy, a phase III clinical trial is open for a 241 liposome combinational delivery of two cytotoxic drugs (cytarabine and daunorubicin) 242 for high risk acute myeloid leukemia (clinicaltrials.gov identifier NCT01696084) (Shi 243 et al., 2017). With the ultimate goal of achieving both spatial and temporal control of 244 drug delivery, nanocarriers have evolved from the mere "sustained" release to 245 "triggered" release (Figure 3). Indeed, in cancer, abnormal local conditions, such as $246 \mathrm{pH}$, enzymatic activity or concentration in reactive oxygen species, can trigger the 247 delivery of the drug. In addition to these endogenous signals, nanocarriers can also 248 release their load on the effect of applied light, ultrasounds or a magnetic field 249 (Bhattacharya et al., 2016; Kamaly et al., 2016). 
250 In the topic of B cell malignancy, only few nanoparticles-based therapies are in 251 development (Stephenson and Singh, 2017) (Shi et al., 2017). Among all the recent 252 clinical-stage nanomedicines (Shi et al., 2017), a phase II clinical trial is open to 253 evaluate a liposome, carrying a DNA oligonucleotide against the anti-apoptotic 254 protein BCL-2, in relapsed or refractory B cell lymphomas (clinicaltrials.gov identifiers 255 NCT01733238 and NCT02226965). Similar approaches of gene/RNAi delivery by 256 silica-based nanoparticles to target B-cell lymphoma were described in mouse model 257 (Martucci et al., 2016). Additionally, between 2011 and 2014, a phase I/II clinical trial 258 was opened to evaluate the safety and tolerability of a poly(ethylenimine)-based 259 transfecting polyplex carrying siRNA against elF5A and a plasmid expressing a pro260 apoptotic mutant of elF5A under the control of a B cell specific promoter. This 261 therapeutic agent was evaluated in relapsed or refractory B cell malignancies 262 (clinicaltrials.gov identifier NCT01435720). Finally, an immunostimulant lipoplex 263 composed of liposome and plasmid DNA (Chang et al., 2009) is in a phase I clinical 264 trial in relapsed or refractory leukemia (clinicaltrials.gov identifier NCT00860522).

265 Tumors are currently diagnosed using various imaging modalities such as 266 radiography, computed tomography $(\mathrm{CT})$, positron emission tomography (PET) and 267 magnetic resonance imaging (MRI) (Salem et al., 2014)(Navarro et al., 2017). 268 However, the diagnosis of hematological malignancies can be challenging due to the 269 diversity of imaging appearances and clinical behavior of these diseases (Navarro et 270 al., 2017). Multimodal imaging approaches have been proposed to overcome these 271 limitations, since they offer the ability to image with different resolutions and over 272 different temporal and spatial scales. Cistaro et al. demonstrated the high potential of 273 combined PET (using ${ }^{18} \mathrm{~F}$-fluorodeoxyglucose) and MRI (using paramagnetic contrast 274 agent) in the evaluation of pediatric patients with ALL (Cistaro et al., 2017). By their 
work, they highlighted the real need of developing hybrid PET/MRI instruments and

276 dual contrasts agents.

277 In line with that idea, a variety of nanoparticles has been designed to combine 278 several imaging modes, multiple therapies, (e.g. photothermal therapy and 279 conventional chemotherapy) or imaging and therapeutic functions (theranostics) and 280 therefore holds great prospects in cancer treatment (Riley and Day, 2017). Among 281 others, our group has recently reported on a vesicular platform, with a shell of 282 inorganic nanoparticles named Hybridosomes ${ }^{\circledR}$ (Sciortino et al., 2016). The large 283 number of nanoparticles forming the shell is a clear advantage for imaging 284 applications, since an enhanced contrast is observed. Initially designed for MRI, 285 these Hybridosomes ${ }^{\circledR}$ can not only be prepared from iron oxide superparamagnetic 286 nanoparticles but also from any types and combinations of inorganic particles with 287 imaging or therapeutic properties. Therefore, those multimodal nano-objects are 288 suitable tools for multimodal imaging as well as theranostics. The feasibility of a 289 theranostic approach has been demonstrated in acute myeloid leukemia patients 290 where in vivo molecular imaging of CXCR4, a crucial protein involved in the retention 291 of hematopoietic stem cells within the hematopoietic niche, has been achieved by 292 means of positron emission tomography (Herhaus et al., 2016). However, as far as 293 we know, there is still no open clinical trial using those combined strategies in B cell 294 malignancies.

\subsection{CD19-TARGETING NANOPARTICLES}

297 The efficiency of imaging and treatment can be greatly improved by targeting 298 specifically the malignant cells. As mentioned above, CD19 is currently the antigen of 
299 choice used to target B cells. Recently, CD19-targeting nanoparticles were designed

300 for nanomedicine by grafting anti-CD19 antibody or its derivatives (Fab, $\left.F(a b)_{2} \ldots\right)$ to

301 the nanoparticles (Figure 4). As an example, Cheng et al. produced liposomal 302 doxorubicin targeted via anti-CD19 monoclonal antibody fragments: either the single303 chain variable fragment (scFv), or the variable fragment (Fab), or the monoclonal 304 antibody (mAb) (Figure 4). The authors compared the efficacy of the three targeted 305 constructs and concluded that the scFv single-chain variable fragment would be 306 more suitable for development of immunotherapy for the following reasons: i) it 307 contained less foreign peptides, ii) the production was easier, and iii) the cost of 308 production was more economical thanks to the expression in bacterial systems 309 (Cheng and Allen, 2008). Typically, four types of chemical functions from the 310 antibody or its derivatives $\left(-\mathrm{NH}_{2},-\mathrm{COOH},-\mathrm{SH},-\right.$ carbohydrates) can be used for 311 covalent grafting to the nanoparticle. The use of spacers such as PEG derivatives 312 lowers the risk of antibody inactivation (Chen et al., 2016; Manjappa et al., 313 2011)(Nguyen et al., 2010)(Hong et al., 2015). Alternative strategies were also 314 proposed, as the noncovalent strepatividin/biotin conjugation (Procko et al., 2014) 315 (Dong et al., 2014).

\subsubsection{Imaging with anti-CD19 nanoparticles}

318 Few anti-CD19 grafted nanoparticles for in vitro imaging have been published so far. Nguyen et al. designed pegylated SERS (Surface Enhanced Raman Scattering) gold nanoparticles conjugated to human anti-CD19 antibody that showed specific in vitro

321 targeting towards chronic lymphocytic leukemia (CLL) (Nguyen et al., 2010; Walker 322 et al., 2012). The functional SERS nanoparticles were composed of a gold core onto 323 which a reporter dye was adsorbed. The signals were detected by dark-field 
324 microscopy and Raman spectrometry and showed no interference with conventional

325 fluorescent stains used in histology. Ramos B cells labeling through anti-CD19

326 mediator was demonstrated by Dong et al. by grafting an anti-CD19 antibody onto $327 \mathrm{Ag} @ \mathrm{SiO}_{2}$ core-shell nanoparticles (Dong et al., 2014). In this study, the authors 328 monitored the metal-enhanced fluorescence of a reporter (rhodamine B) adsorbed on 329 the surface of the nanoparticles. However, to the best of our knowledge, in vivo 330 imaging using anti-CD19-grafted-nanoparticles has not been reported yet.

\subsubsection{Therapy with anti-CD19 nanoparticles}

\subsubsection{Chemotherapy: drug delivery}

Nanoparticles decorated with anti-CD19 have already been reported as effective carriers for drug delivery on in vitro models and preclinical studies (Table 2). Doxorubicin, an inhibitor of topoisomerase involved in DNA synthesis, is frequently the drug of choice for proof-of-concept, as the cytotoxic effect of this drug is well demonstrated on B cells. A doxorubicin loaded immunoliposome targeting B lymphocytes showed a 6-fold more cytotoxic in vitro activity on B cells than nontargeted liposomes (Lopes de Menezes et al., 1998). Similar results were observed in vivo with an improved survival of mice injected with anti-CD19-doxorubicinliposomes compared to non-targeted liposomes or free doxorubicin treatments (Lopes de Menezes et al., 1998). Doxorubicin was also encapsulated into blockcopolymer nanoparticles grafted with anti-CD19. A clathrin-dependent internalization pathway was identified, suggesting that the physiological internalization pathway of CD19 was conserved. In comparison to the administration of free doxorubicin, both improved in vitro apoptosis of CD19 positive cells and better survival of treated mice were demonstrated (Krishnan et al., 2015). In vivo, mice xenografted with B cells and 
exposed to anti-CD19-liposomes containing doxorubicin or vincristine demonstrated a higher cell cytotoxicity and showed a longer survival time than mice exposed to free

351 drug (Sapra and Allen, 2004). Those anti-CD19-liposomes showed in vitro a greater 352 binding, a more effective internalization and an equivalent cytotoxicity on B cells 353 compared to anti-CD20-liposomes (Sapra and Allen, 2004).

354 Other inhibitors of B-cells than doxorubicin or vincristine have also been evaluated 355 and incorporated into nanoparticles. As an example, the C61 molecule (1,4-bis (9-O356 dihydroquinidinyl) phthalazine/hydroquinidine 1,4-phathalazinediyl diether) was 357 identified as a potent inhibitor of the cytoplasmic protein SYK (spleen tyrosine 358 kinase), an important regulator of $\mathrm{B}$ cell apoptosis (Table 2). Myers et al. 359 demonstrated that a liposomal nanoparticle formulation entrapping C61 and 360 decorated with anti-CD19 caused in vitro the apoptosis of pre-B ALL cells, twice 361 more than the non-decorated liposomes (Myers et al., 2014). Immunocompromised 362 NOD/SCID mice were then xenografted with pre-B ALL cells, and injected with C61363 liposomes decorated with anti-CD19. Tumor cell viability decreased and mice did not 364 develop leukemic splenomegaly, thus showing a better therapeutic efficacy than 365 irradiation with 2Gy y-rays. In addition, the combination of C61 loaded anti-CD19366 liposomal nanoparticles, with exposure to low dose of radiations, caused the 367 abrogation of B leukemia in engrafted mice (Myers et al., 2014).

369 In addition, multifunctional immunoliposomes grafted with several antibodies were 370 shown to exhibit higher selectivity, greater binding affinity, and enhanced apoptosis 371 induction of B-CLL cells (Woyach et al., 2014). Yu et al. also proposed a dual ligand 372 conjugation on immunoliposomes (Yu et al., 2013). The authors first evaluated the 373 level of expression of CD19, CD20 and CD37 antigens in several B cell lines and 
374 primary B-CLL cells, and found comparable level for CD19 and CD37. They also 375 calculated the internalization rate of the three antibodies in Iymphoma cells (Raji 376 cells) and confirmed the choice of anti-CD37 as the primary ligand for specific 377 targeting of B cells. Then they measured the binding efficacy of single or mixtures of 378 anti-CD19, anti-CD20 and anti-CD37 on B-CLL cells isolated from patients. Greater 379 binding efficacies occurred with dual combinations of anti-CD19 and anti-CD20, with 380 anti-CD37 antibody. The antibody ratio was finally optimized to improve this synergetic effect.

383 Note that the combination of several specific antibodies is also a promising strategy 384 to overcome the variability in the expression of target antigens among patients. In 385 this context, hydroxychloroquine, an anti-malaria and anti-rheumatic drug, has been encapsulated in order to overcome pharmacokinetic obstacles and to deliver a larger amount of this apoptotic drug into B-CLL cells from patients. As an example, Mansilla et al. encapsulated hydroxychloroquine in PEG-PLGA nanoparticles mono-

389 functionalized by anti-CD19 antibody or bi-functionalized by anti-CD19 and anti390 CD20 antibodies (Mansilla et al., 2010). The authors showed a significant induction 391 of apoptosis of B-CLL cells with mono- or bi-functionalized nanoparticles compared 392 to non-functionalized nanoparticles.

\subsubsection{Nanoparticle-based immunotherapy}

395 An innovative strategy consists in using nanoparticles exposing antibodies in order to 396 stimulate the production of lymphocytes, or even to bridge malignant cells to killer T cells (see the graphical abstract). Schütz et al. designed nanoparticles termed antigen-specific T cells redirectors (ATR). The ATR nanoparticles were conjugated to 
399 two antibodies, an anti-TCR and an anti-CD19. The ATR nanoparticles provided a 400 physical proximity between T cells and tumor cells, and redirected T cells to kill tumor 401 cells (Schütz et al., 2016). In vivo assays on mice xenografted with lymphoma cells 402 and injected with ATR nanoparticles showed smaller tumors and an improved 403 survival compared to control mice.

404

\section{CD19-TARGETED CHIMERIC ANTIGEN RECEPTOR (CAR) T CELLS} IMMUNOTHERAPY

An alternative to nanoparticles for targeting tumor cells is to take advantage of other cells. For years, most of hematological neoplasms have been treated by hematopoietic stem cell transplantations. The transplanted allogeneic hematopoietic

411 stem cells kill residual malignant cells by a graft-versus-tumor effect. This cell therapy 412 approach, used to fight leukemia, lymphoma or myeloma, leads to either remission or 413 immune control of the malignancy; however, some patients relapse. On the other 414 hand, many therapeutic approaches tend to modulate the immune response to 415 eliminate tumor cells. Immunotherapy has marked the past years by generating extraordinary advances in clinical applications for cancer treatment.

417 Cell immunotherapy harnesses the power of both cell therapy and immunotherapy, 418 and is at the origin of tremendous clinical progresses in the past decade 419 (Ramachandran et al., 2017). For the purpose of the review, we will focus on CD19 420 antibody-based cell immunotherapies that target B cell neoplasms. 


\subsubsection{The concept of CAR T cell: retargeting a cytolytic immune cell by genetic-} modification to eliminate a tumor cell

T lymphocytes are cells that play a central role in cell-mediated immunity. Different subsets of $\mathrm{T}$ cells achieve cytolytic, regulatory or memory roles. Genetically

427 retargeting $\mathrm{T}$ cells against tumor surface antigens to trigger cytotoxic mechanisms 428 against malignant cells is one of the principles of adoptive cell therapy. More 429 precisely, the engineering of T cells to express a chimeric antigen receptor (CAR) is the most common gene-modifying strategy that is being investigated. CARs are

431 synthetic receptors that direct the genetically engineered $\mathrm{T}$ cells against tumor 432 surface antigens, for instance CD19 antigen. Adoptive cell therapy using gene433 modified $\mathrm{T}$ cells has emerged as an exciting therapeutic approach for the treatment 434 of cancer (Porter et al., 2011; Kochenderfer et al., 2012 ; Brentjens et al., 2013).

\subsubsection{The main biological challenges for an effective antibody-based adoptive cellular} therapy

438 Conceptually, many challenges should be faced to achieve an in vivo therapeutic 439 efficacy. The first one is that CAR T cells must be able to persist in vivo, and then 440 undergo cellular expansion (Grupp et al., 2013). They will also have to infiltrate tumor 441 tissues (in case of solid tumors), then to engage their target antigen expressed on 442 tumor cells, and finally, to exert their cytolytic, proliferative, and cytokine secretory 443 activities within the tumor microenvironment to eliminate malignant cells (review in 444 (Beatty and O'Hara, 2016)).

445 Adoptive $\mathrm{T}$ cell therapy with chimeric antigen receptor engineered T cells (CAR T 
cells) has shown substantial clinical results against B cell malignancies (Porter et al.,

447 2011; Kochenderfer et al., 2012 ; Brentjens et al., 2013). The fact that CAR T cell

448 therapy approach has proven to be of some effectiveness across a range of 449 hematological malignancies (Gill and June, 2015) may be partly explained by the 450 choice of a relevant target antigen (for instance CD19) and by the fact that those 451 malignancies reside in the natural sites that adoptively transferred $\mathrm{T}$ cells naturally 452 invade (review in (Newick et al., 2016).

\subsubsection{The choice of a relevant target antigen: CD19 gene therapy}

As mentioned previously, CD19 is a reliable target antigen for antibody-based

456 therapy (review in (Hammer, 2012)(Li et al., 2017)). More than half of all CAR457 modified $\mathrm{T}$ cell studies in hematological malignancies have targeted CD19 antigen 458 (review in (Beatty and O'Hara, 2016)). CD19-specific CAR T cells have demonstrated 459 potent activity in B cell ALL and lymphomas including CLL and non-Hodgkin 460 Iymphoma (Porter et al., 2011 ; Grupp et al., 2013; Maude et al., 2014 ; Davila et al., 4612014 ; Lee et al., 2015 ; Brudno et al., 2016 ; review in Beatty and O'Hara, 2016).

\subsubsection{The role of CAR: conferring T cell the ability to persist and expand in vivo and to} exert cytolytic activity

\subsubsection{Design of CAR}

466 The chimeric antigen receptor (CAR) is composed by two main modules: (i) an 467 extracellular component that recognizes a cell surface protein (e.g. CD19) (this 468 extracellular moiety is a single-chain variable fragment (scFv) derived from an 469 antibody) linked to (ii) an intracellular component consisting in $\mathrm{T}$ cell signaling 


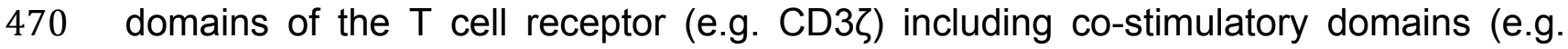

$471 \mathrm{CD} 28$, or 4-1BB) involved in $\mathrm{T}$ cell activation (Figure 5) (review in (Beatty and

472 O'Hara, 2016) and (Geyer and Brentjens, 2016)). The extracellular component is 473 responsible for redirecting $T$ cell specifically to the human tumor antigen whereas the 474 intracellular component sustains $T$ cell activation, supporting cell expansion and 475 cytokine release resulting in cytolytic activity.

476 Intense work is done to optimize each module: the extracellular component which 477 acts as the target-binding domain of the CAR, the hinge region connecting 478 extracellular and intracellular component (Hudecek et al., 2013), and the intracellular 479 component for an effective $\mathrm{T}$ cell proliferation and differentiation to mature effector $\mathrm{T}$ 480 cells. The successive generations of CD19 CAR T differ in the number and origin of 481 the intracellular co-stimulatory domains (Figure 5) (e.g. 4-1BB or CD28) (Savoldo et 482 al., 2011 ; Porter et al., 2011 ; Maude et al., 2014 ; Park et al., 2016).

\subsubsection{Mechanism of action of CAR T cells}

485 The binding of the anti-CD19 scFV to CD19 antigen of tumor cell surface (the 486 resulting complex is named the immune synapse) sends a signal through the CAR to 487 the effector T cell. This signal results in the activation of the T cell and in the release 488 of soluble molecules, perforin, granzyme and pro-apoptotic ligands, that kill the tumor cells. Additionally, activated T cells secrete proinflammatory cytokines (e.g. interferon 490 IFN- $y$, and IL-2), amplifying the immune response (Davenport et al., 2015) (Geyer 491 and Brentjens, 2016), and leading to the expansion of CAR T cells. The range of in 492 vivo expansion of CAR T cells has been reported between 100- to 10 000- fold 493 (Grupp et al., 2013). 


\section{THERAPY}

497

\subsubsection{Clinical outcomes}

499 Many patients go into remission with standard chemotherapy for B cell malignancies.

500 However, children and adults with relapsed or refractory B cell ALL have a poor 501 prognosis. Substantial clinical efficacy has been demonstrated with a therapy based 502 on CAR-modified T cells targeted to CD19. Approximately $70 \%$ of patients underwent 503 complete or at least partial response to treatment with chimeric antigen receptor 504 CAR-modified T cells targeted to CD19 (Porter et al., 2011; Kochenderfer et al., 2012 505 ; Brentjens et al., 2013 ; Grupp et al., 2013 ; Maude et al., 2014 ; Davila et al., 2014 ;

506 Lee et al., 2015). Results are less impressive with CLL or with B cell non-Hodgkin 507 lymphoma but still subsets of patients show significant benefits (review in (Geyer and 508 Brentjens, 2016). Clinical trials are ongoing for multiple myeloma.

509

\subsubsection{Advantages}

511 In vivo expansion and persistence of CAR T cells is a clear determinant of clinical 512 benefit (Grupp et al., 2013 ; Porter et al., 2015 ; Beatty and O'Hara, 2016). In 513 addition, the natural trafficking of CAR T cells within the blood, lymph nodes, and 514 bone marrow where they encounter malignant cells also favors the efficacy of the 515 therapy (Beatty and O'Hara, 2016). Furthermore, it appears that the accessibility to 516 malignant cells is less hindered by the tumor microenvironment in those tissues 517 compared to solid tumors (Geyer and Brentjens, 2016 ; Newick et al., 2016). 


\subsubsection{Limitations}

520

521 First, each patient is infused with his own T cells. This specificity limits any large522 scale manufacturing process and anticipated stocks. Then, autologous $\mathrm{T}$ cells are 523 subjected to genetic modifications by retrovirus, lentivirus or non-viral gene transfer 524 followed by in vitro stimulation. Currently, the complicated and individualized 525 production of autologous CAR T cells may be one, among others, of the bottlenecks that reduce accessibility to this personalized therapy to many people. Some

527 strategies using universal T cells (i.e. that do not come from the patient) are also in 528 development. Suboptimal expression of the CAR at the surface of CAR T cells may 529 also limit the benefit of CAR T cell therapies. Recently, Eyquem et al. have proposed 530 that directing a CD19-specific CAR to the T cell receptor $\alpha$ constant (TRAC) locus not 531 only results in uniform CAR expression in human peripheral blood T cells, but also 532 enhances $\mathrm{T}$ cell potency, with edited cells vastly outperforming conventionally generated CAR T cells in a mouse model of ALL (Eyquem et al., 2017).

534

\subsubsection{The need of lymphodepletion for the patient}

536 The purpose of chemotherapy, whose objective is to achieve lymphodepletion prior 537 to CAR T cells infusion, is to create a more favorable environment for CAR T cells.

538 Most studies corroborated the notion that host lymphopenia (i.e. a low number of 539 lymphocytes in the blood) facilitates the expansion of adoptively transferred T cells. 540 Whether lymphodepletion might further enhance the activity of CAR T cells in this 541 setting remains unclear (Brudno et al., 2016 ; Turtle et al., 2016). To date, induction 
542 of lymphodepletion prior to infusion of CAR T cells continues to be often incorporated

543 in clinical trials using CAR T cells.

544

\subsubsection{Toxicity for the patient}

546 The medical community will have to overcome clinical challenges related to CD19-

547 targeted CAR T cells (Geyer and Brentjens, 2016; Park et al., 2016). Major side-

548 effects, particularly cytokine release syndrome, neurological toxicities, and B cell 549 aplasia have been reported in all clinical trials using CD19-targeted CAR T cells. The

550 cytokine release syndrome is a severe inflammatory response syndrome that 551 appears within the hours to days following CAR T cell infusion. Clinical features 552 include fevers, muscle pain, malaise, and, in more severe cases, hypoxia, 553 hypotension, and occasionally renal dysfunction and coagulopathy. The cytokine 554 release syndrome is characterized by elevation of pro-inflammatory cytokines (e.g. 555 IL-6) and T cell activation and expansion. Tumor burden is positively correlated with 556 the risks of severe cytokine release syndrome and neurotoxicity (Brentjens et al., 557 2013) (Turtle et al., 2016). The cytokine release syndrome can be life-threatening 558 and requires intensive supportive care. Mitigating strategies to reduce cytokine 559 release syndrome frequency and severity comprise anti-IL-6 receptor antibody, 560 steroids, and possibly a protocol-specified algorithm to potentially start pre-emptive 561 treatments (Maude et al., 2014; Lee et al., 2014 ;Turtle et al., 2016; Ruella et al., 562 2017).

563 Reversible neurologic toxicity has been observed after CAR T cell infusion, including 564 delirium, seizure-like activity, confusion, word-finding difficulty, or aphasia.

565 Finally, CD19-targeted CAR T cells therapy shows "on-target, off-tumor" toxicity that 566 generates B cell aplasia (Porter et al., 2011 ;Grupp et al., 2013; Maude et al., 2014). 
Limiting B cell aplasia for CD19-targeted CAR $\mathrm{T}$ cells has been successfully managed with intravenous immunoglobulin replacement therapy (Frey and Porter, 2016). Novel approaches to limit B cell aplasia are under investigation as the use of antigen-specific inhibitory CAR to protect normal B cells (Fedorov et al., 2013).

\subsubsection{CD19-antigen escape}

573 Loss of expression of the CD19-target antigen resulting in an antigen escape (e.g. 574 CD19-negative relapse) may limit the benefit of CD19 CAR T cells therapy (Grupp et al., 2013). Tumor antigen escape has emerged as a main challenge for the long-term disease control (review in (Wang et al., 2017; Velasquez and Gottschalk, 2017)).

577 Studies are going on to understand the mechanism of loss of CD19 expression and 578 overcome this difficulty. Braig et al. reported emergence of CD19-relapses due to 579 CD19 mRNA splice variants (Braig et al., 2017). Zah et al. proposed a design of 580 bispecific CARs that triggered robust cytotoxicity against target cells expressing 581 either CD19 or CD20 and controlled both wild-type B cell lymphoma and CD19 582 mutants with equal in vivo efficacy (Zah et al., 2016).

\subsubsection{Infused dose, composition, and control of expansion and function of CAR T cells}

585 So far, the different clinical trials have not led to the identification of a clear correlation between higher CAR T cell infused dose and greater efficacy or CAR T cell persistence (Porter et al., 2011 ; Grupp et al., 2013; Maude et al., 2014 ; Davila 588 et al., 2014 ; Lee et al., 2015 ; Brudno et al., 2016) (review in (Park et al., 2016;

589 Geyer and Brentjens, 2016)). Importantly, the efficacy of CAR T cells relies on their 590 activation in response to CD19 antigen and expansion in vivo, making the magnitude 591 of their reactivity unpredictable (Grupp et al., 2013). For instance, anti-CD19 CAR T 
592 cells have been shown to proliferate in excess of 100,000 -fold in some patients, 593 ultimately accounting for over $50 \%$ of circulating lymphocytes. The lack of control 594 over CAR T cells activation and expansion in vivo is a limit to predict the therapeutic 595 response.

596 Multiple parameters provide clues to explain this unpredictability. The composition of 597 the infused therapeutic agent is source of variability. So far, CAR T cells are 598 generated from autologous T cells, making the received therapeutic agent different 599 for each patient (Sommermeyer et al., 2016) (Turtle et al., 2016). In preclinical 600 studies, where mice were injected with a same pool of CAR T cells, a better 601 correlation between the infused dose and the xenografted mouse survival was 602 observed (Sommermeyer et al., 2016). More precisely, the variability of CAR T cells 603 encompasses extrinsic parameters, from the efficacy of genetic modification to the expression of the CAR at the surface of CAR T cells, but also intrinsic interindividual parameters including composition of CD4+ and CD8+ T cells. In CAR T therapy, 606 CD4+ CAR T cells are responsible for cytokine production whereas CD8+ CAR T 607 cells trigger direct antitumor effects. The ratio of CD4+/CD8+ CAR T cell subsets 608 may be of importance in the balance between efficacy and toxicity (Park et al., 2016).

609 In most reported trials, patients received CAR T products comprising random 610 compositions of CD4+ and CD8+ T cells. In contrast, Sommermeyer et al. and Turtle 611 et al. showed that CAR T cell products generated from defined T cell subsets $(1: 1$ 612 ratio of CD4+ and CD8+ CAR T cells) can provide uniform potency compared with 613 products derived from unselected $\mathrm{T}$ cells and induce complete remission without a 614 high rate of toxicity in patients with a high tumor burden (Sommermeyer et al., 2016 ; 615 Turtle et al., 2016). Approaches to limit expansion and activation are also underway. 616 Rodgers et al. propose a method to control CAR T cells using peptide-engrafted 
617 antibody-based molecular switches that act as a bridge between the target cell and

618 CAR T cells (Rodgers et al., 2016).

619 Interindividual variation in response to the treatment can also be attributed to

620 difference in lymphodepletion between each patient, or to difference in immunological

621 clearance that will impact the persistence of the infused and expanded CAR T cells.

622 Altogether, the optimal dose and composition of the CAR T cell product remain under

623 development in order to achieve a better predictability in response to the therapeutic

624 agent and to balance toxicity and efficacy.

625

626

4 PERSPECTIVES: HOW NANOPARTICLES AND CAR T CELL THERAPY COULD BE COMPLEMENTARY?

\subsection{MULTIMODALITY}

631 The efficacy of CAR $\mathrm{T}$ cell therapy relies on the multimodality of the therapeutic response. CAR T cells target tumor cells, trigger cytolytic activity, and ensure their own expansion. We can envision that the future of nanomedicine will benefit from the

634 same feature: the multimodality. It is clear that nano-objects, and among them 635 Hybridosomes ${ }^{\circledR}$ (Sciortino et al., 2016), can address many of the challenging issues 636 of hematological cancer diagnosis and therapy. In particular, nanoparticles could play 637 a significant role for the potentiation of, and the cooperation with CAR T cell therapy. 638 Their complementarity (in terms of function, distribution and time of administration) 639 can be envisioned to fulfill at least three objectives: (i) to track malignant cells and 
640 CAR T cells to monitor their biodistribution and expansion, (ii) to increase tumor 641 accessibility, and (iii) to manage CAR T cell toxicity and modulate the expansion of 642 CAR T cells.

643

\subsection{TO TRACK MALIGNANT AND CAR T CELLS}

645 Since the proof-of-concept of CAR T cells has been validated, current developments

646 include the control of cell expansion or avoidance of CD19 escape. There is a need

647 for noninvasive tracking of the transfused $T$ cells in patients to determine their 648 biodistribution, viability, and functionality (review in (Liu and Li, 2014)). Several 649 strategies based on nanoparticle contrast agents have been proposed using either ex 650 vivo preloaded nanoparticles on CAR $\mathrm{T}$ cells, or in vivo administration of 651 nanoparticles after CAR T cell infusion. For instance, in mouse model, CAR T 652 biodistribution has been monitored through radiolabeled-nanoparticles or contrast653 agent-nanoparticles loaded into CAR T cells prior to cell infusion (Bhatnagar et al., 654 2013;Bhatnagar et al., 2014).

655 Furthermore, detecting the localization of tumor cells is of particular importance in the 656 case of hematological cancer, since hematological malignant cells are intrinsically 657 disseminating. In addition, in situ imaging alternatives to the invasive sampling of 658 bone marrow are desirable for diagnosis and for residual disease follow-up. By 659 proposing efficient targeting contrast agents, nanomedicine can greatly improve the 660 diagnosis, and beyond, the determination of localization of tumor cells (Kobayashi et 661 al., 2005). 
664 A recent statistical review of the literature revealed that less than $1 \%$ of the injected 665 nanoparticles systemically reaches the malignant cells in solid tumors, compromising 666 their translation into clinical use (Wilhelm et al., 2016). This figure is due both to 667 nanoparticle uptake by the immune system, and to their poor mobility into the tumor 668 microenvironment. Although hematological malignancies differ from other solid 669 tumors, some limitations of the CAR T therapy due to limited access to specific 670 accumulation sites may be observed as well. According to cancer type, 671 hematological malignant cells originate from the bone marrow (e.g. leukemia, 672 myeloma) or lymph node (e.g. lymphoma), and infiltrate blood stream and solid 673 tissues. The bone marrow niche is a very complex environment essentially 674 composed of a dense network of small arterioles and sinusoids, and of various cell 675 types within an extracellular matrix (Wu et al., 2008) (Morrison and Scadden, 2014) 676 (Gattazzo et al., 2014)(Schepers et al., 2015). Leukemic stem cells, as well as 677 hematopoietic stem cells, are dependent on those cells and extracellular components 678 for their emergence, homing and survival. Disruption of those interactions 679 participates in the efficacy of the therapy.

680 The combination of the specific properties of CAR T cells and nanoparticles seems 681 promising to enhance the efficacy of treatments. Indeed, CAR T cells will guarantee 682 longer circulation time in the blood stream and specific recognition of B cells, 683 whereas nanoparticles can bring advantageous features such as degradation of the 684 extracellular matrix, disruption of cell-cell interactions, or thermal stimulation. An 685 advance in this direction was already reported in the literature. In mouse studies, 686 Kennedy et al. used T cell as chaperones for gold nanoparticle delivery to enhance 687 the efficacy of nanoparticle-based photothermal therapies and imaging applications 
688

by increasing accumulation at tumor site (Kennedy et al., 2011). Another innovative

689 strategy, inspired by motile and invasive cells, would be the active enzymatic

690 degradation of the tumor matrix by protease that can be associated with the

691 nanotherapeutic system. For instance, iron oxide nanoparticles coated with

692 collagenase were magnetically driven through in vitro extracellular matrix, at a rate

693 similar to invasive cells (Kuhn et al., 2006). Other proteolytic surfaces include

694 bromelain, an enzymatic complex belonging to the papain family and extracted from

695 pineapple which contains a mixture of 9 proteases with distinct $\mathrm{pH}$ and enzymatic

696 activities (Parodi et al., 2014). Local heating triggered by external sources can also

697 be used to alter the tumor environment and enhance accessibility to malignant cells,

698 based on gold nanoparticles (Gormley et al., 2013; Smith et al., 2015).

699 An alternative strategy would be the pretreatment with therapeutic nanoparticles prior

700 to CAR-T infusion. In this line, nanoparticles targeting the bone marrow niche could

701 also be utilized to specifically deliver high doses of lymphodepleting agents prior to

702 CAR T infusion. Similarly, pre-treatment with drugs, specifically targeting the

703 interaction of leukemic stem cells with their bone marrow niches, may be useful to

704 mobilize those cells and render them more accessible to CAR T cells in the marrow

705 or the blood stream. Among others, inhibitors of the adhesion molecule E-selectin, or

706 inhibitors of the chemoattractant stromal-cell-derived factor 1 (SDF-1) could be

707 proposed because leukemic stem cells are dependent on those molecules for their

708 homing (Sipkins et al., 2005)(Krause and Scadden, 2015)(Schepers et al., 2015).

709 Identification of additional specific factors in B cell malignancies could be of interest

710 for mobilizing B cells and enhancing CAR T cell therapy, as exemplified by the role of

711 CD44, or various selectins and their ligands in chronic myeloid leukemia or acute

712 myeloid leukemia (Krause et al., 2006)(Jin et al., 2006)(Krause et al., 2013). 


\subsection{TO MANAGE TOXICITIES OF CAR T CELLS AND MODULATE THE EXPANSION OF}

716 Major toxicity such as severe cytokine release syndrome is intrinsically related to

717 CAR T efficacy, and current developments aim at controlling it. Current strategies to 718 allow preferential removal of CAR T cells include genetic "safety switch" or drug 719 sensitivity (review in (Ranganathan and Foster, 2016)). In this perspective, 720 nanoparticles could be specifically designed to target CAR T cells, making possible a 721 selective apoptosis of those cells or a selective removal of those cells. In this line, an 722 innovative strategy related to hematological diseases is the magnetic sorting of sick 723 cells, after attachment of a magnetic particle. In some cases, such as malaria, the 724 intrinsic magnetic properties of infected cells even allow magnetic sorting of 725 unlabeled cells (Zborowski and Chalmers, 2011). Nanoparticles targeting tumor cells 726 or CAR T cells could be used to lower the tumor burden (lymphodepletion) before 727 treatment or alternatively remove CAR T, after treatment or in case of excessive 728 expansion of CAR T cells.

729

730

\section{CONCLUSION}

732 Nanomedicine and cell therapy are two fields that have grown in parallel. Yet, those

733 approaches aim ultimately at common goals, to achieve long remission and ideally 734 the cure of the patients. In this review, based on the example of developing tools to 735 target B cell malignancy (mostly anti-CD19 nano-objects and anti-CD19 CAR T 
736 cells), we have discussed their specificity, limitations and potential complementarity.

737 It appears that even if CART T cell therapy has revolutionized management of

738 patients presenting poor prognosis B cell malignancy, improvements are needed,

739 especially to predict the therapeutic response, to control the intensity and persistence

740 of the treatment, to increase tumor accessibility of the therapeutic agent to leukemic

741 stem cell niches, and to visualize residual leukemic clones, and thus prevent

742 relapses. Therefore, therapeutic developments could benefit from nanoparticles

743 advantages -mainly their multimodality combining imaging and loading capacity, their

744 tendency to accumulate at tumor sites for solid tumors and their relative easiness to

745 be produced- to fill those requirements. 
TABLES

748

749 Table 1: Main chemical and physical properties of the different types of nanoparticles

750 used in nanomedicine and their principal applications. Note that the given size

751 corresponds to the primary nano-object. In the case of small nanoparticles (NP) such

752 as dendrimers or quantum dots (QD), surface modification with PEG or other

753 macromolecules result in larger dimension.

754

755

\begin{tabular}{|c|c|c|c|}
\hline NP type & Size $(\mathrm{nm})$ & Organic/lnorganic & Principal application \\
\hline Liposome & $30-500$ & organic & encapsulation \\
\hline Polymer NP & $10-200$ & organic & encapsulation \\
\hline Polymersome & $50-1000$ & organic & encapsulation \\
\hline Dendrimer & $<10$ & organic & $\begin{array}{l}\text { encapsulation / } \\
\text { imaging }\end{array}$ \\
\hline $\begin{array}{c}\text { Solid Lipid NP } \\
\text { (and emulsion based particles) }\end{array}$ & $>100$ & organic & encapsulation \\
\hline Silica NP & all range & inorganic & $\begin{array}{l}\text { encapsulation / } \\
\text { imaging }\end{array}$ \\
\hline Quantum dot & $5-20$ & inorganic & imaging \\
\hline SPION & $5-100$ & inorganic & imaging \\
\hline Au NP & $5-100$ & inorganic & imaging / therapy \\
\hline Hybridosome $®$ & $80-120$ & organic/inorganic & $\begin{array}{c}\text { imaging / } \\
\text { encapsulation / } \\
\text { therapy }\end{array}$ \\
\hline
\end{tabular}


Table 2: Nanoparticles (NP) grafted with anti-CD19 antibody and their applications in nanomedicine.

759 Abbreviation: Ag Silver; Au: Gold; Chol: Choline; DOTAP: 1,2-dioleoyl-3-trimethylammoniumpropane; DOPE: dioleoylphosphatidylethanolamine; DSPE: Distearoylphosphatidylethanolamine; EggPC: Egg yolk phosphatidylcholine; HD37-CCH: Hybridomas HD37-c-myc-Cys-His5 scFv; HSPC: hydrogenated soy phosphatidylcholine; LNP: liposomal nanoparticle ; MHC-Ig: Major Histocompatibility ComplexImmunoglobulin; NHS: N-hydroxysuccinimide; PEG: Polyethylene glycol; PLGA: poly(lactic-co-glycolic acid); SERS: Surface Enhanced Raman Scattering; SiO2: Silicon dioxide ; SYK: Spleen Tyrosine Kinase; TCR: T cell receptor

\begin{tabular}{|c|c|c|c|c|c|}
\hline NP type & Composition & Targeting agent & $\begin{array}{l}\text { Size } \\
(\mathrm{nm}) \\
\end{array}$ & Application & Reference \\
\hline Liposome & PEG-DSPE & anti-CD19 & $100-120$ & $\begin{array}{c}\text { doxorubicin carrier } \\
140-160 \mu \mathrm{g} / \mu \mathrm{mol} \text { of } \\
\text { phospholipid }\end{array}$ & $\begin{array}{c}\text { Lopes de Menezes et } \\
\text { al., } 1998\end{array}$ \\
\hline Liposome & $\begin{array}{l}\text { HSPC/Chol/ } \\
\text { mPEG-DSPE }\end{array}$ & anti-CD19 & $90-110$ & doxorubicin carrier & $\begin{array}{l}\text { Sapra and Allen, } \\
2004\end{array}$ \\
\hline Liposome & $\begin{array}{l}\text { SM/Chol/ } \\
\text { mPEG-DSPE }\end{array}$ & anti-CD19 & $110-130$ & vincristin carrier & $\begin{array}{l}\text { Sapra and Allen, } \\
2004\end{array}$ \\
\hline Liposome & $\mathrm{mPEG}_{2000}-\mathrm{DSPE}$ & $\begin{array}{c}\text { anti-CD19 } \\
\text { hd37-cch fragment }\end{array}$ & $80-120$ & doxorubicin carrier & $\begin{array}{l}\text { Cheng and Allen, } \\
2008\end{array}$ \\
\hline Liposome & $\begin{array}{l}\text { EggPC/Chol/ } \\
\text { PEG }_{2000}-\text { DSPE }\end{array}$ & $\begin{array}{c}\text { anti-CD19 + anti-CD37 / } \\
\text { anti-CD19 + anti-CD20 + } \\
\text { anti-CD37 }\end{array}$ & 100 & FTY720 carrier & Yu et al.,2013 \\
\hline Liposome & DSPE-PEG $3400-\mathrm{NHS}$ & mouse anti-CD19 & $\sim 135$ & $\begin{array}{c}\text { C61 carrier } \\
9,4 \mathrm{mg} / \mathrm{mL}\end{array}$ & Myers et al., 2014 \\
\hline $\begin{array}{l}\text { Polymer } \\
\text { NP }\end{array}$ & PEG-PLGA & $\begin{array}{c}\text { anti-CD19 / } \\
\text { anti-CD19 + anti-CD20 }\end{array}$ & $\sim 300$ & $\begin{array}{c}\text { hydroxychloroquine } \\
\text { carrier } \\
165 \mu \mathrm{g} / \mathrm{mg} \text { of polymer }\end{array}$ & Mansilla et al., 2010 \\
\hline $\begin{array}{l}\text { Polymer } \\
\text { NP }\end{array}$ & $\mathrm{EG}_{113} \mathrm{CL}_{152} \mathrm{TSU}_{25}$ & anti-CD19 & $\sim 60$ & $\begin{array}{l}\text { doxorubicin carrier } \\
72,1+/-6,4 \mu \mathrm{g} / \mathrm{mg} \text { of polymer }\end{array}$ & Krishnan et al., 2015 \\
\hline Inorganic & Au@PEG & human anti-CD19 & $60-80$ & $\begin{array}{l}\text { SERS cell imaging } \\
M G I T C=\text { Raman tag }\end{array}$ & Nguyen et al., 2010 \\
\hline Inorganic & $\mathrm{Ag} @ \mathrm{SiO}_{2}$ & anti-CD19 & $100-140$ & $\begin{array}{l}\text { Fluorescence cell } \\
\text { imaging }\end{array}$ & Dong et al., 2014 \\
\hline Inorganic & $\begin{array}{c}\text { Iron } \\
\text { oxide@dextran }\end{array}$ & $\begin{array}{c}\text { pep-MHC-Ig dimer } \\
\text { or anti-TCR-specific } \\
\text { with anti-human CD19 }\end{array}$ & $\sim 50$ & $\begin{array}{c}\text { Targeting } \\
\text { Redirect } T \text { cells against tumor } \\
\text { cells }\end{array}$ & Schütz et al., 2016 \\
\hline
\end{tabular}


FIGURE LEGENDS

770

771 Figure 1: B cell development and differentiation

772 B cell development begins in bone marrow and progresses through pre pro B cell, 773 pro B cell, small pre B cell, large pre B cell and immature pre B cell. B cell locates 774 within the circulatory system from mature B cell stage. The CD19 protein is 775 expressed from pro B cell stage.

776

Figure 2: CD19 signaling complex and activation pathways

(A) Schematic representation of the CD19 signaling complex. The CD19 complex is composed of CD21, CD81 and CD19 transmembrane proteins. CD19 possesses an intracellular tail with multiple tyrosine-kinase residues involved in signal transduction.

781 (B) The first pathway of CD19 activation is dependent on the B cell receptor (BCR): it is a co-receptor for BCR signal transduction. The second pathway is independent of the BCR: the CD19 complex is able to bind activated complement fragment C3d and modulates BCR signaling (Figure adapted from (Wang et al., 2012)).

Figure 3: The two main modes of controlled release from carrier nanoparticles

Sustained release can be operated by biodegradable carriers, most often polymeric, which are progressively eroded, or by porous (silica, polymer...) particles. Triggeractivated particles deliver their load at once, upon activation by an endogenous or exogenous trigger. 
794 (A) Schematic representation of full monoclonal antibody (mAb) of $150 \mathrm{kDa}$ and its $795 \mathrm{scFv}$ derivative of $55 \mathrm{kDa}$. Functional groups present on the antibodies and available 796 for covalent labeling or bioconjugation are schematically represented (amine groups, 797 carboxylate groups, thiol groups and carbohydrate residues). Fab: variable region; Fc 798 region: constant region; VL: Variable Light chain; VH: Variable Heavy chain; CL: 799 Constant Light chain; $\mathrm{CH}$ : Constant Heavy chain.

800 (B) Comparison between mAb and its derivatives in terms of size, pharmacokinetics, 801 valency/specificity and strengths/weaknesses.

802

803 Figure 5: Chimeric antigen receptor (CAR)

804 Chimeric antigen receptor (CAR) of second generation is composed of a targeting 805 element (here the single chain variable fragment (scFv) of anti-CD19), a 806 transmembrane domain, a co-stimulatory domain and a signaling domain. 


\section{LIST OF ABBREVIATIONS}

ALL: acute lymphoblastic leukemia

Ag: Silver

Au: Gold

BCR: B cell receptor

B-ALL: B cell acute lymphoblastic leukemia

CAR: chimeric antigen receptor,

CL: Constant Light chain;

$\mathrm{CH}$ : Constant Heavy chain

Chol: Choline

CLL : chronic lymphocytic leukemia

DOTAP: 1,2-dioleoyl-3-trimethylammoniumpropane

DOPE: dioleoylphosphatidylethanolamine

DSPE: Distearoylphosphatidylethanolamine

EC : European Commission

EDC: (1-ethyl-3-(3- dimethyl-aminopropyl)carbodiimide hydrochloride EggPC: Egg yolk phosphatidylcholine

EPR : Enhanced Permeation and Retention

Fab: variable region

Fc region: constant region

FDA : US Food-and-Drug-Administration

IFNy : interferon gamma

IL6: interleukin 6

HD37-CCH: Hybridomas HD37-c-myc-Cys-His5 scFv

HSPC: hydrogenated soy phosphatidylcholine

LNP: liposomal nanoparticle

mAb: monoclonal antibody

MGITC: Malachite Green Isothiocyanate

MHC-Ig: Major Histocompatibility Complex-Immunoglobulin

MPS: mononuclear phagocyte system

MRI : Magnetic Resonance Imaging

$\mathrm{MRI} / \mathrm{CT}$ : magnetic resonance imaging/ computerized tomography

MRI/PET : magnetic resonance imaging/ positron emission tomography

NHS: N-hydroxysuccinimide

NP:nanoparticle

PEG: Polyethylene glycol

PLGA: poly(lactic-co-glycolic acid)

PVP: polyvinylpyrrolidone

QD: quantum dots

RES : reticuloendothelial system

SERS: Surface Enhanced Raman Scattering

SiO2: Silicon dioxide

siRNA:small interference RNA

SMCC: N-succinimidyl 4-(N maleimidomethyl)cyclohexane-1-carboxylate

SPDP: N-succinimidyl 3-(2-pyridylthio)propionate

SPECT: single, photon emission computed tomography

scFv: single-chain variable fragment

SYK: Spleen Tyrosine Kinase

TCR: T cell receptor 
858 TEM: transmission electron microscopy

859 UCNPs : up-converting nanoparticles

860 VL: Variable Light chain

861 VH: Variable Heavy chain

862 


\section{ACKNOWLEDGEMENTS/FUNDING}

864 This work is supported by SFR Biosit UMS CNRS 3480 - INSERM 018 (Call 865 Interdisciplinary Project, SC, FG, MBT), Université de Rennes 1 (Call Scientific 866 Challenge, SC, FG, MBT), French Ministry of Research (HJ, FS), the Sociétés 867 d'Accélération du Transfert de Technologies Ouest Valorisation (SC, FG, FS), Ligue 868 régionale contre le cancer (comity $22,35,56,79,41)(\mathrm{MBT})$, the Société française de 869 lutte contre les cancers et les leucémies de l'enfant et de l'adolescent and the 870 Fédération Enfants et Santé (MBT), a private donator Mrs. M-Dominique Blanc 871 (MBT), the CNRS (MBT, FG), and the People Programme (Marie Curie Actions) of 872 the European Union's Seventh Framework Programme (FP7/2007-2013) under REA 873 grant agreement $\mathrm{n}^{\circ} 291851$ (MBT).

874 
Beatty, G.L., and O'Hara, M. (2016). Chimeric antigen receptor-modified T cells for the treatment of solid tumors: Defining the challenges and next steps. Pharmacol. Ther. 166, 30-39. Bhatnagar, P., Li, Z., Choi, Y., Guo, J., Li, F., Lee, D.Y., Figliola, M., Huls, H., Lee, D.A., Zal, T., et al. (2013). Imaging of Genetically Engineered T Cells by PET using Gold Nanoparticle Complexed to Copper-64. Integr. Biol. Quant. Biosci. Nano Macro 5, 231. A., Ferrari, M., Li, K.C., et al. (2014). Tumor Lysing Genetically Engineered T Cells Loaded with Multi-Modal Imaging Agents. Sci. Rep. 4. Bhattacharya, S., Ganivada, M.N., Dinda, H., Das Sarma, J., and Shunmugam, R. (2016). Biodegradable Copolymer for Stimuli-Responsive Sustained Release of Doxorubicin. ACS Omega 1, 108-117.

Braig, F., Brandt, A., Goebeler, M., Tony, H.-P., Kurze, A.-K., Nollau, P., Bumm, T., Böttcher, S., Bargou, R.C., and Binder, M. (2017). Resistance to anti-CD19/CD3 BiTE in acute lymphoblastic leukemia may be mediated by disrupted CD19 membrane trafficking. Blood 129, 100-104.

Brentjens, R., Davila, M.L., Riviere, I., Park, J., Wang, X., Cowell, L.G., Bartido, S., Stefanski, J., Taylor, C., Olszewska, M., et al. (2013). CD19-targeted T cells rapidly induce molecular remissions in adults with chemotherapy-refractory acute lymphoblastic leukemia. Sci. Transl. Med. 5, 177ra38.

Brudno, J.N., Somerville, R.P.T., Shi, V., Rose, J.J., Halverson, D.C., Fowler, D.H., GeaBanacloche, J.C., Pavletic, S.Z., Hickstein, D.D., Lu, T.L., et al. (2016). Allogeneic T Cells That Express an Anti-CD19 Chimeric Antigen Receptor Induce Remissions of B-Cell Malignancies That Progress After Allogeneic Hematopoietic Stem-Cell Transplantation Without Causing Graft-Versus-Host Disease. J. Clin. Oncol. 34, 1112. Carter, P.J. (2006). Potent antibody therapeutics by design. Nat. Rev. Immunol. 6, 343357.

Chang, S., Warner, J., Liang, L., and Fairman, J. (2009). A novel vaccine adjuvant for recombinant flu antigens. Biol. J. Int. Assoc. Biol. Stand. 37, 141-147.

Chen, G., Roy, I., Yang, C., and Prasad, P.N. (2016). Nanochemistry and nanomedicine for nanoparticle-based diagnostics and therapy. Chem. Rev. 116, 2826-2885.

Cheng, W.W.K., and Allen, T.M. (2008). Targeted delivery of anti-CD19 liposomal doxorubicin in B-cell lymphoma: A comparison of whole monoclonal antibody, Fab' fragments and single chain Fv. J. Controlled Release 126, 50-58.

Cistaro, A., Delfa, V.L., Rosa, G.D., Cogoni, M., and Quartuccio, N. (2017). MRI and 18FFDG-PET/CT in a rare case of early (precursor) B-lymphoblastic leukaemia with bone involvement as initial manifestation. Nucl. Med. Rev. 20, 57-59. Davenport, A.J., Jenkins, M.R., Cross, R.S., Yong, C.S., Prince, H.M., Ritchie, D.S., Trapani, J.A., Kershaw, M.H., Darcy, P.K., and Neeson, P.J. (2015). CAR-T Cells Inflict Sequential Killing of Multiple Tumor Target Cells. Cancer Immunol. Res. 3, 483-494. Davila, M.L., Riviere, I., Wang, X., Bartido, S., Park, J., Curran, K., Chung, S.S., Stefanski, J., Borquez-Ojeda, O., Olszewska, M., et al. (2014). Efficacy and Toxicity Management of 1928z CAR T Cell Therapy in B Cell Acute Lymphoblastic Leukemia. Sci. Transl. Med. 6, 224ra25-224ra25. 
Dong, M., Tian, Y., and Pappas, D. (2014). Facile functionalization of Ag@SiO2 core-shell metal enhanced fluorescence nanoparticles for cell labeling. Anal. Methods 6, 15981602.

Eyquem, J., Mansilla-Soto, J., Giavridis, T., van der Stegen, S.J.C., Hamieh, M., Cunanan, K.M., Odak, A., Gönen, M., and Sadelain, M. (2017). Targeting a CAR to the TRAC locus with CRISPR/Cas9 enhances tumour rejection. Nature 543, 113-117. Frey, N.V., and Porter, D.L. (2016). The Promise of Chimeric Antigen Receptor T-Cell Therapy | Cancer Network. Gattazzo, F., Urciuolo, A., and Bonaldo, P. (2014). Extracellular matrix: A dynamic microenvironment for stem cell niche. Biochim. Biophys. Acta 1840, 2506.

Gerber, H.-P., Kung-Sutherland, M., Stone, I., Morris-Tilden, C., Miyamoto, J., McCormick, R., Alley, S.C., Okeley, N., Hayes, B., Hernandez-Ilizaliturri, F.J., et al. (2009). Potent antitumor activity of the anti-CD19 auristatin antibody drug conjugate hBU12-vcMMAE against rituximab-sensitive and -resistant lymphomas. Blood 113, 4352-4361.

Geyer, M.B., and Brentjens, R.J. (2016). Review: Current clinical applications of chimeric antigen receptor (CAR) modified T cells. Cytotherapy 18, 1393-1409.

Gill, S., and June, C.H. (2015). Going viral: chimeric antigen receptor T-cell therapy for hematological malignancies. Immunol. Rev. 263, 68-89.

Goebeler, M.-E., and Bargou, R. (2016). Blinatumomab: a CD19/CD3 bispecific T cell engager (BiTE) with unique anti-tumor efficacy. Leuk. Lymphoma.

Gormley, A.J., Larson, N., Banisadr, A., Robinson, R., Frazier, N., Ray, A., and Ghandehari, H. (2013). Plasmonic photothermal therapy increases the tumor mass penetration of HPMA copolymers. J. Controlled Release 166, 130-138. Greish, K. (2007). Enhanced permeability and retention of macromolecular drugs in solid tumors: a royal gate for targeted anticancer nanomedicines. J. Drug Target. 15, 457-464.

Grupp, S.A., Kalos, M., Barrett, D., Aplenc, R., Porter, D.L., Rheingold, S.R., Teachey, D.T., Chew, A., Hauck, B., Wright, J.F., et al. (2013). Chimeric Antigen Receptor-Modified T Cells for Acute Lymphoid Leukemia.

Hammer, 0. (2012). CD19 as an attractive target for antibody-based therapy. MAbs 4, 571-577.

Herhaus, P., Habringer, S., Philipp-Abbrederis, K., Vag, T., Gerngross, C., Schottelius, M., Slotta-Huspenina, J., Steiger, K., Altmann, T., Weißer, T., et al. (2016). Targeted positron emission tomography imaging of CXCR4 expression in patients with acute myeloid leukemia. Haematologica 101, 932-940.

Hong, E.E., Erickson, H., Lutz, R.J., Whiteman, K.R., Jones, G., Kovtun, Y., Blanc, V., and Lambert, J.M. (2015). Design of Coltuximab Ravtansine, a CD19-Targeting AntibodyDrug Conjugate (ADC) for the Treatment of B-Cell Malignancies: Structure-Activity Relationships and Preclinical Evaluation.

Hudecek, M., Lupo-Stanghellini, M.-T., Kosasih, P.L., Sommermeyer, D., Jensen, M.C., Rader, C., and Riddell, S.R. (2013). Receptor Affinity and Extracellular Domain Modifications Affect Tumor Recognition by ROR1-Specific Chimeric Antigen Receptor T Cells. Clin. Cancer Res. 19, 3153-3164.

Jin, L., Hope, K.J., Zhai, Q., Smadja-Joffe, F., and Dick, J.E. (2006). Targeting of CD44 eradicates human acute myeloid leukemic stem cells. Nat. Med. 12, 1167-1174. Kamaly, N., Yameen, B., Wu, J., and Farokhzad, O.C. (2016). Degradable controlledrelease polymers and polymeric nanoparticles: mechanisms of controlling drug release. Chem. Rev. 116, 2602-2663.

Kennedy, L.C., Bear, A.S., Young, J.K., Lewinski, N.A., Kim, J., Foster, A.E., and Drezek, R.A. 
(2011). T cells enhance gold nanoparticle delivery to tumors in vivo. Nanoscale Res. Lett. 6, 283.

Kochenderfer, J.N., Dudley, M.E., Feldman, S.A., Wilson, W.H., Spaner, D.E., Maric, I., Stetler-Stevenson, M., Phan, G.Q., Hughes, M.S., Sherry, R.M., et al. (2012). B-cell depletion and remissions of malignancy along with cytokine-associated toxicity in a clinical trial of anti-CD19 chimeric-antigen-receptor-transduced T cells. Blood 119, 2709-2720.

Krause, D.S., and Scadden, D.T. (2015). A hostel for the hostile: the bone marrow niche in hematologic neoplasms. Haematologica 100, 1376-1387.

Krause, D.S., Lazarides, K., Andrian, U.H. von, and Etten, R.A.V. (2006). Requirement for CD44 in homing and engraftment of BCR-ABL|[ndash]|expressing leukemic stem cells. Nat. Med. 12, 1175-1180.

Krause, D.S., Fulzele, K., Catic, A., Sun, C.C., Dombkowski, D., Hurley, M.P., Lezeau, S., Attar, E., Wu, J.Y., Lin, H.Y., et al. (2013). Differential regulation of myeloid leukemias by the bone marrow microenvironment. Nat. Med. 19, 1513-1517.

Krishnan, V., Xu, X., Kelly, D., Snook, A., Waldman, S.A., Mason, R.W., Jia, X., and Rajasekaran, A.K. (2015). CD19-Targeted Nanodelivery of Doxorubicin Enhances Therapeutic Efficacy in B-Cell Acute Lymphoblastic Leukemia. Mol. Pharm. 12, 21012111.

Kuhn, S.J., Finch, S.K., Hallahan, D.E., and Giorgio, T.D. (2006). Proteolytic Surface Functionalization Enhances in Vitro Magnetic Nanoparticle Mobility through Extracellular Matrix. Nano Lett. 6, 306-312.

LeBien, T.W., and Tedder, T.F. (2008). B lymphocytes: how they develop and function. Blood 112, 1570-1580.

Lee, D.W., Gardner, R., Porter, D.L., Louis, C.U., Ahmed, N., Jensen, M., Grupp, S.A., and Mackall, C.L. (2014). Current concepts in the diagnosis and management of cytokine release syndrome. Blood 124, 188-195.

Lee, D.W., Kochenderfer, J.N., Stetler-Stevenson, M., Cui, Y.K., Delbrook, C., Feldman, S.A., Fry, T.J., Orentas, R., Sabatino, M., Shah, N.N., et al. (2015). T cells expressing CD19 chimeric antigen receptors for acute lymphoblastic leukaemia in children and young adults: a phase 1 dose-escalation trial. The Lancet 385, 517-528.

Li, X., Ding, Y., Zi, M., Sun, L., Zhang, W., Chen, S., and Xu, Y. (2017). CD19, from bench to bedside. Immunol. Lett. 183, 86-95.

Liu, Z., and Li, Z. (2014). Molecular Imaging in Tracking Tumor-Specific Cytotoxic T Lymphocytes (CTLs). Theranostics 4, 990-1001.

Lopes de Menezes, D.E., Pilarski, L.M., and Allen, T.M. (1998). In vitro and in vivo targeting of immunoliposomal doxorubicin to human B-cell lymphoma. Cancer Res. 58, 3320-3330. Ma, D., McDevitt, M.R., Barendswaard, E., Lai, L., Curcio, M.J., Pellegrini, V., Brechbiel, M.W., and Scheinberg, D.A. (2002). Radioimmunotherapy for model B cell malignancies using 90Y-labeled anti-CD19 and anti-CD20 monoclonal antibodies. Leukemia 16, 60-66. Maeda, H., Wu, J., Sawa, T., Matsumura, Y., and Hori, K. (2000). Tumor vascular permeability and the EPR effect in macromolecular therapeutics: a review. J. Control. Release Off. J. Control. Release Soc. 65, 271-284.

Manjappa, A.S., Chaudhari, K.R., Venkataraju, M.P., Dantuluri, P., Nanda, B., Sidda, C., Sawant, K.K., and Ramachandra Murthy, R.S. (2011). Antibody derivatization and conjugation strategies: Application in preparation of stealth immunoliposome to target chemotherapeutics to tumor. J. Controlled Release 150, 2-22.

Mansilla, E., Marin, G.H., Nuñez, L., Drago, H., Sturla, F., Mertz, C., Rivera, L., Ichim, T., 
Riordan, N., and Raimondi, C. (2010). The Lysosomotropic Agent, Hydroxychloroquine, Chronic Lymphocytic Leukemia Cells In Vitro. Cancer Biother. Radiopharm. 25, 97-103. Martucci, N.M., Migliaccio, N., Ruggiero, I., Albano, F., Calì, G., Romano, S., Terracciano, M., Rea, I., Arcari, P., and Lamberti, A. (2016). Nanoparticle-based strategy for personalized B-cell lymphoma therapy. Int. J. Nanomedicine 11, 6089.

Maude, S.L., Frey, N., Shaw, P.A., Aplenc, R., Barrett, D.M., Bunin, N.J., Chew, A., Gonzalez, V.E., Zheng, Z., Lacey, S.F., et al. (2014). Chimeric Antigen Receptor T Cells for Sustained Remissions in Leukemia. N. Engl. J. Med. 371, 1507-1517.

Moghimi, S., Hunter, A., and Murray, J. (2001). Long-Circulating and Target-Specific Nanoparticles: Theory to Practice. Pharmacol. Rev. 53, 283-318.

Morrison, S.J., and Scadden, D.T. (2014). The bone marrow niche for haematopoietic stem cells. Nature 505, 327-334.

Myers, D.E., Yiv, S., Qazi, S., Ma, H., Cely, I., Shahidzadeh, A., Arellano, M., Finestone, E., Gaynon, P.S., Termuhlen, A., et al. (2014). CD19-antigen specific nanoscale liposomal formulation of a SYK P-site inhibitor causes apoptotic destruction of human B-precursor leukemia cells. Integr. Biol. 6, 766.

Navarro, S.M., Matcuk, G.R., Patel, D.B., Skalski, M., White, E.A., Tomasian, A., and Schein, A.J. (2017). Musculoskeletal Imaging Findings of Hematologic Malignancies. Radiogr. Rev. Publ. Radiol. Soc. N. Am. Inc 37, 881-900.

Newick, K., Moon, E., and Albelda, S.M. (2016). Chimeric antigen receptor T-cell therapy for solid tumors. Mol. Ther. Oncolytics 3, 16006.

Nguyen, C.T., Nguyen, J.T., Rutledge, S., Zhang, J., Wang, C., and Walker, G.C. (2010). Detection of chronic lymphocytic leukemia cell surface markers using surface enhanced Raman scattering gold nanoparticles. Cancer Lett. 292, 91-97.

Park, J.H., Geyer, M.B., and Brentjens, R.J. (2016). CD19-targeted CAR T-cell therapeutics for hematologic malignancies: interpreting clinical outcomes to date. Blood 127, 33123320.

Parodi, A., Haddix, S.G., Taghipour, N., Scaria, S., Taraballi, F., Cevenini, A., Yazdi, I.K., Corbo, C., Palomba, R., Khaled, S.Z., et al. (2014). Bromelain Surface Modification Increases the Diffusion of Silica Nanoparticles in the Tumor Extracellular Matrix. ACS Nano 8, 9874-9883.

Pattni, B.S., Chupin, V.V., and Torchilin, V.P. (2015). New Developments in Liposomal Drug Delivery. Chem. Rev. 115, 10938-10966.

Perica, K., Medero, A.D.L., Durai, M., Chiu, Y.L., Bieler, J.G., Sibener, L., Niemöller, M., Assenmacher, M., Richter, A., Edidin, M., et al. (2014). Nanoscale Artificial Antigen Presenting Cells for T Cell Immunotherapy. Nanomedicine Nanotechnol. Biol. Med. 10, 119.

Porter, D.L., Levine, B.L., Kalos, M., Bagg, A., and June, C.H. (2011). Chimeric Antigen Receptor-Modified T Cells in Chronic Lymphoid Leukemia.

Procko, E., Berguig, G.Y., Shen, B.W., Song, Y., Frayo, S., Convertine, A.J., Margineantu, D., Booth, G., Correia, B.E., Cheng, Y., et al. (2014). A computationally designed inhibitor of an Epstein-Barr viral Bcl-2 protein induces apoptosis in infected cells. Cell 157, 1644. Ramachandran, M., Dimberg, A., and Essand, M. (2017). The cancer-immunity cycle as rational design for synthetic cancer drugs: Novel DC vaccines and CAR T-cells. Semin. Cancer Biol. Ranganathan, R., and Foster, M.C. (2016). The Limitations and Promise of Immunotherapy With Chimeric Antigen-Modified T Cells | Cancer Network. Riley, R.S., and Day, E.S. (2017). Gold nanoparticle-mediated photothermal therapy: 
applications and opportunities for multimodal cancer treatment. Wiley Interdiscip. Rev. Nanomed. Nanobiotechnol. n/a-n/a. Rodgers, D.T., Mazagova, M., Hampton, E.N., Cao, Y., Ramadoss, N.S., Hardy, I.R., Schulman, A., Du, J., Wang, F., Singer, O., et al. (2016). Switch-mediated activation and retargeting of CAR-T cells for B-cell malignancies. Proc. Natl. Acad. Sci. 113, E459-E468. Ruella, M., Kenderian, S.S., Shestova, O., Klichinsky, M., Melenhorst, J.J., Wasik, M.A., Lacey, S.F., June, C.H., and Gill, S. (2017). Kinase inhibitor ibrutinib to prevent cytokinerelease syndrome after anti-CD19 chimeric antigen receptor T cells for B-cell neoplasms. Leukemia 31, 246-248.

Salem, U., Menias, C.O., Shaaban, A., Bhosale, P.R., Youssef, A., and Elsayes, K.M. (2014). Hematopoietic tumors of the female genital system: imaging features with pathologic correlation. Abdom. Imaging 39, 922-934.

Sapra, P., and Allen, T.M. (2004). Improved outcome when B-cell lymphoma is treated with combinations of immunoliposomal anticancer drugs targeted to both the CD19 and CD20 epitopes. Clin. Cancer Res. Off. J. Am. Assoc. Cancer Res. 10, 2530-2537.

Savoldo, B., Ramos, C.A., Liu, E., Mims, M.P., Keating, M.J., Carrum, G., Kamble, R.T., Bollard, C.M., Gee, A.P., Mei, Z., et al. (2011). CD28 costimulation improves expansion and persistence of chimeric antigen receptor-modified T cells in lymphoma patients. J. Clin. Invest. 121, 1822.

Scheinberg, D.A., and Strand, M. (1983). Kinetic and Catabolic Considerations of Monoclonal Antibody Targeting in Erythroleukemic Mice. Cancer Res. 43, 265-272. Schepers, K., Campbell, T.B., and Passegué, E. (2015). Normal and Leukemic Stem Cell Niches: Insights and Therapeutic Opportunities. Cell Stem Cell 16, 254.

Schütz, C., Varela, J.C., Perica, K., Haupt, C., Oelke, M., and Schneck, J.P. (2016). Antigenspecific T cell Redirectors: a nanoparticle based approach for redirecting $\mathrm{T}$ cells. Oncotarget.

Sciortino, F., Casterou, G., Eliat, P.-A., Troadec, M.-B., Gaillard, C., Chevance, S., Kahn, M.L., and Gauffre, F. (2016a). Simple Engineering of Polymer-Nanoparticle Hybrid Nanocapsules. ChemNanoMat 2, 796-799.

Sciortino, F., Casterou, G., Eliat, P.-A., Troadec, M.-B., Gaillard, C., Chevance, S., Kahn, M.L., and Gauffre, F. (2016b). Simple Engineering of Polymer-Nanoparticle Hybrid Nanocapsules. ChemNanoMat 2, 796-799.

Shi, J., Kantoff, P.W., Wooster, R., and Farokhzad, O.C. (2017). Cancer nanomedicine: progress, challenges and opportunities. Nat. Rev. Cancer 17, 20-37.

Sipkins, D.A., Wei, X., Wu, J.W., Runnels, J.M., Côté, D., Means, T.K., Luster, A.D., Scadden, D.T., and Lin, C.P. (2005). In vivo imaging of specialized bone marrow endothelial microdomains for tumour engraftment. Nature 435, 969-973.

Smith, B.E., Roder, P.B., Zhou, X., and Pauzauskie, P.J. (2015). Nanoscale materials for hyperthermal theranostics. Nanoscale 7, 7115-7126.

Sommermeyer, D., Hudecek, M., Kosasih, P.L., Gogishvili, T., Maloney, D.G., Turtle, C.J., and Riddell, S.R. (2016). Chimeric antigen receptor-modified T cells derived from defined CD8+ and CD4+ subsets confer superior antitumor reactivity in vivo. Leukemia $30,492-500$.

Stamenkovic, I., and Seed, B. (1988). CD19, the earliest differentiation antigen of the B cell lineage, bears three extracellular immunoglobulin-like domains and an Epstein-Barr virus-related cytoplasmic tail. J. Exp. Med. 168, 1205-1210.

Stephenson, R., and Singh, A. (2017). Drug discovery and therapeutic delivery for the treatment of B and T cell tumors. Adv. Drug Deliv. Rev.

Tedder, T.F., Zhou, L.J., and Engel, P. (1994). The CD19/CD21 signal transduction 
complex of B lymphocytes. Immunol. Today 15, 437-442.

Turtle, C.J., Hanafi, L.-A., Berger, C., Gooley, T.A., Cherian, S., Hudecek, M., Sommermeyer, D., Melville, K., Pender, B., Budiarto, T.M., et al. (2016). CD19 CAR-T cells of defined CD4+:CD8+ composition in adult B cell ALL patients. J. Clin. Invest. 126, 2123-2138. Uckun, F.M., Jaszcz, W., Ambrus, J.L., Fauci, A.S., Gajl-Peczalska, K., Song, C.W., Wick, M.R., Myers, D.E., Waddick, K., and Ledbetter, J.A. (1988a). Detailed studies on expression and function of CD19 surface determinant by using B43 monoclonal antibody and the clinical potential of anti-CD19 immunotoxins. Blood 71, 13-29.

Uckun, F.M., Jaszcz, W., Ambrus, J.L., Fauci, A.S., Gajl-Peczalska, K., Song, C.W., Wick, M.R., Myers, D.E., Waddick, K., and Ledbetter, J.A. (1988b). Detailed studies on expression and function of CD19 surface determinant by using B43 monoclonal antibody and the clinical potential of anti- CD19 immunotoxins. Blood 71,13-29.

Uckun, F.M., Qazi, S., and Cheng, J. (2015a). Targeting leukemic stem cells with multifunctional bioactive polypeptide nanoparticles. Future Oncol. 11, 1149-1152.

Uckun, F.M., Ma, H., Cheng, J., Myers, D.E., and Qazi, S. (2015b). CD22 $\Delta$ E12 as a molecular target for RNAi therapy. Br. J. Haematol. 169, 401-414.

Velasquez, M.P., and Gottschalk, S. (2017). Targeting CD19: the good, the bad, and CD81. Blood 129, 9-10.

Walker, G.C., Maclaughlin, C.M., and Ip, S. (2012). Lipid Encapsulation of Surface Enhanced Raman Scattering (sers) Nanoparticles.

Wang, K., Wei, G., and Liu, D. (2012). CD19: a biomarker for B cell development, lymphoma diagnosis and therapy. Exp. Hematol. Oncol. 1, 1.

Wang, Z., Wu, Z., Liu, Y., and Han, W. (2017). New development in CAR-T cell therapy. J. Hematol. Oncol.J Hematol Oncol 10.

Wilhelm, S., Tavares, A.J., Dai, Q., Ohta, S., Audet, J., Dvorak, H.F., and Chan, W.C.W. (2016). Analysis of nanoparticle delivery to tumours. Nat. Rev. Mater. 1, 16014. Wong, J.K.L., Mohseni, R., Hamidieh, A.A., MacLaren, R.E., Habib, N., and Seifalian, A.M. (2017). Will Nanotechnology Bring New Hope for Gene Delivery? Trends Biotechnol. Woyach, J.A., Awan, F., Flinn, I.W., Berdeja, J.G., Wiley, E., Mansoor, S., Huang, Y., Lozanski, G., Foster, P.A., and Byrd, J.C. (2014). A phase 1 trial of the Fc-engineered CD19 antibody XmAb5574 (MOR00208) demonstrates safety and preliminary efficacy in relapsed CLL. Blood 124, 3553.

Yan, J., Wolff, M.J., Unternaehrer, J., Mellman, I., and Mamula, M.J. (2005). Targeting antigen to CD19 on B cells efficiently activates T cells. Int. Immunol. 17, 869-877. yin, H., Liao, L., and Fang, J. (2014). Enhanced Permeability and Retention (EPR) Effect Based Tumor Targeting: The Concept, Application and Prospect. 2, 1010.

Yu, B., Mao, Y., Yuan, Y., Yue, C., Wang, X., Mo, X., Jarjoura, D., Paulaitis, M.E., Lee, R.J., Byrd, J.C., et al. (2013). Targeted drug delivery and cross-linking induced apoptosis with anti-CD37 based dual-ligand immunoliposomes in B chronic lymphocytic leukemia cells. Biomaterials 34, 6185-6193.

Zah, E., Lin, M.-Y., Silva-Benedict, A., Jensen, M.C., and Chen, Y.Y. (2016). T Cells Expressing CD19/CD20 Bispecific Chimeric Antigen Receptors Prevent Antigen Escape by Malignant B Cells. Cancer Immunol. Res. 4, 498-508.

Zborowski, M., and Chalmers, J.J. (2011). Rare Cell Separation and Analysis by Magnetic Sorting. Anal. Chem. 83, 8050-8056.

Zhu, J., and Emerson, S.G. (2002). Hematopoietic cytokines, transcription factors and lineage commitment. 


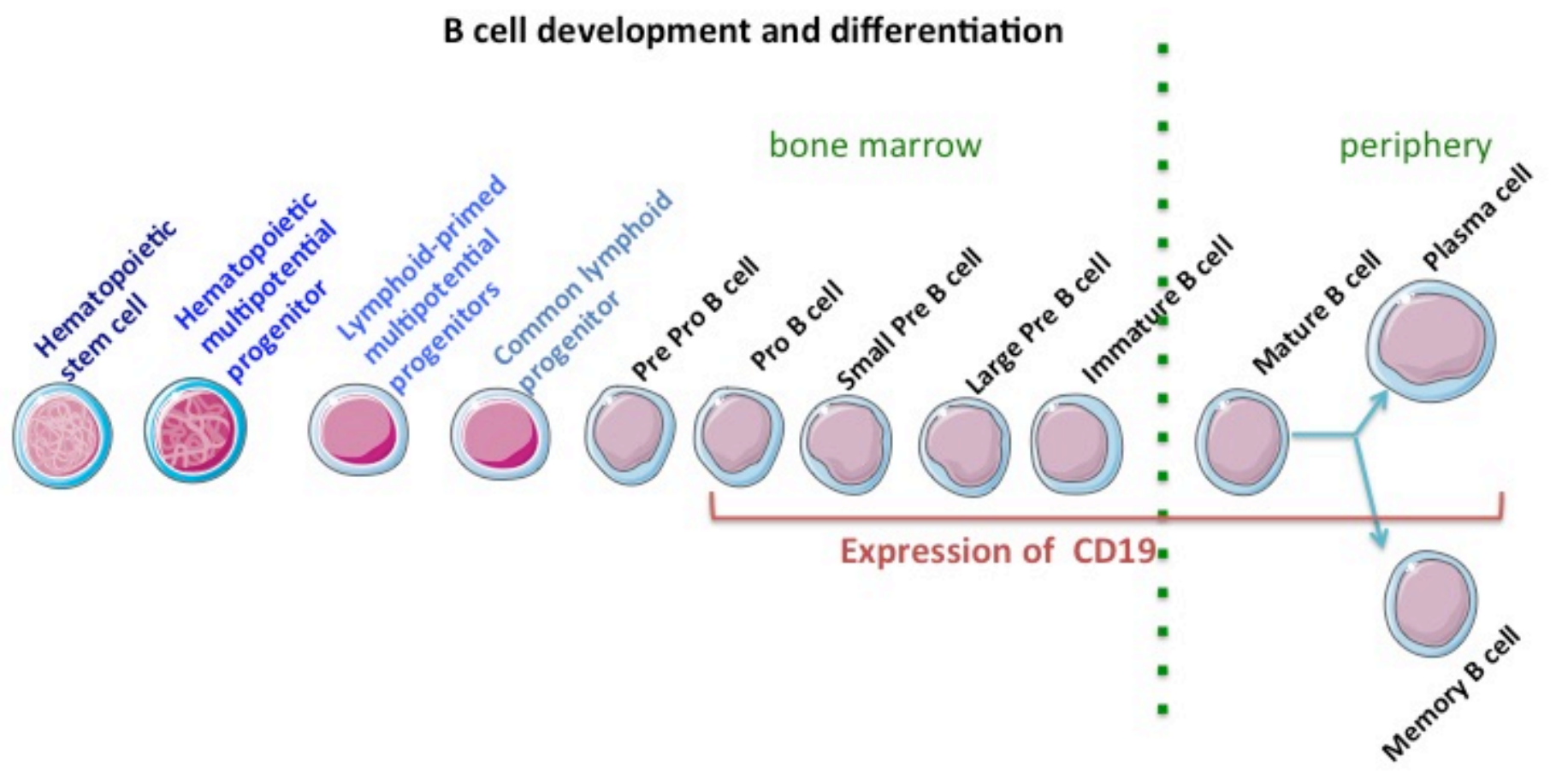

FIGURE 1 
A CD19 signaling complex

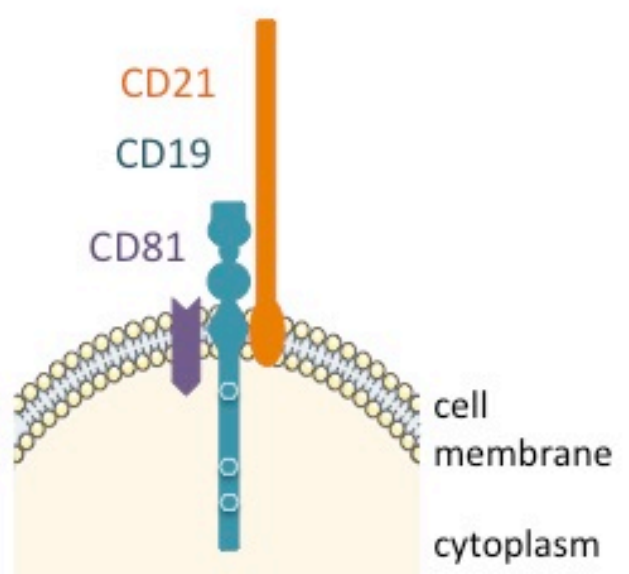

B cell
B CD19 activation pathways

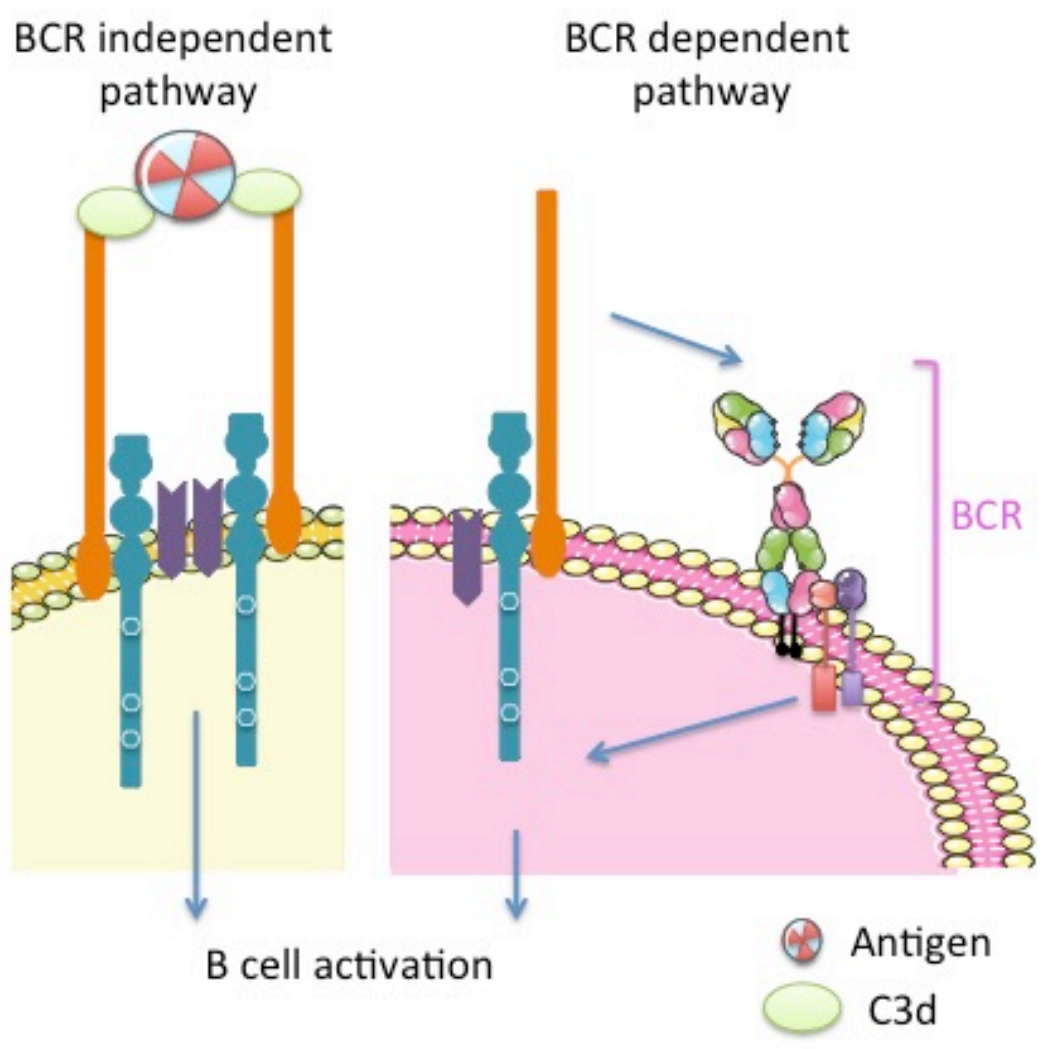

FIGURE 2 

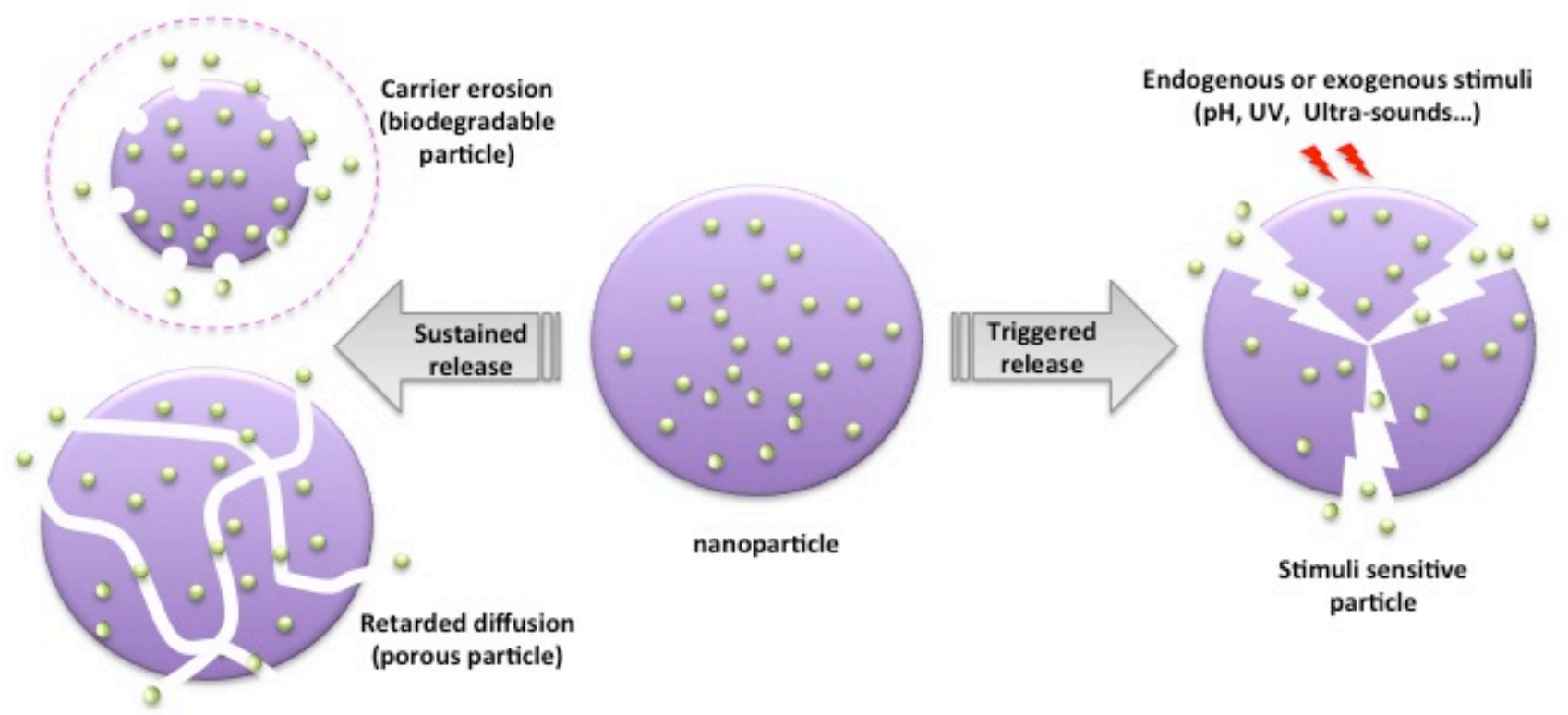

FIGURE 3 


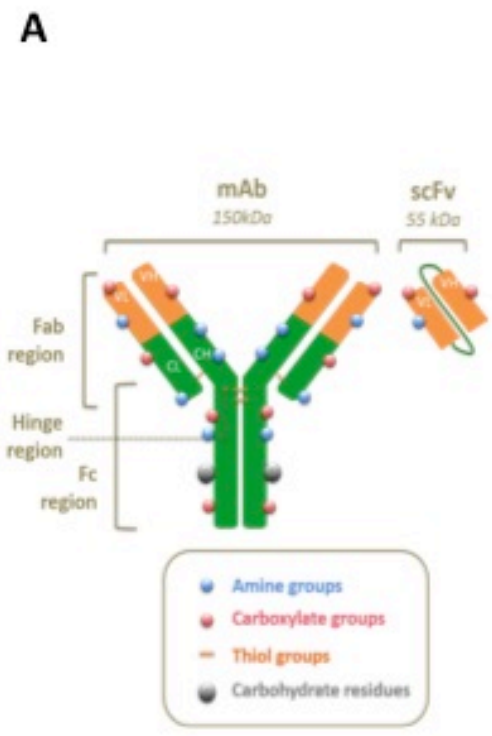

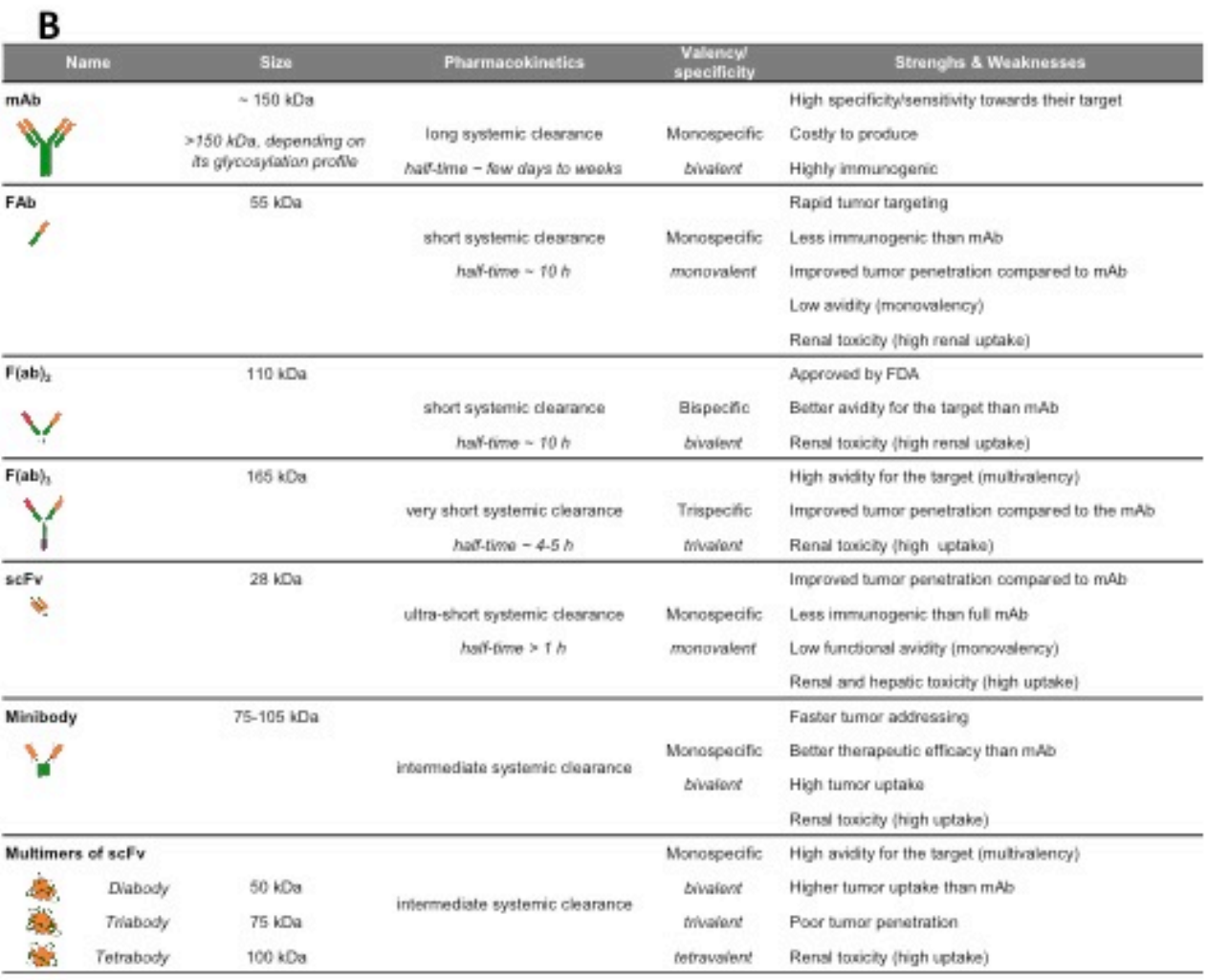

FIGURE 4 


\section{Anti-CD19 CAR second generation}

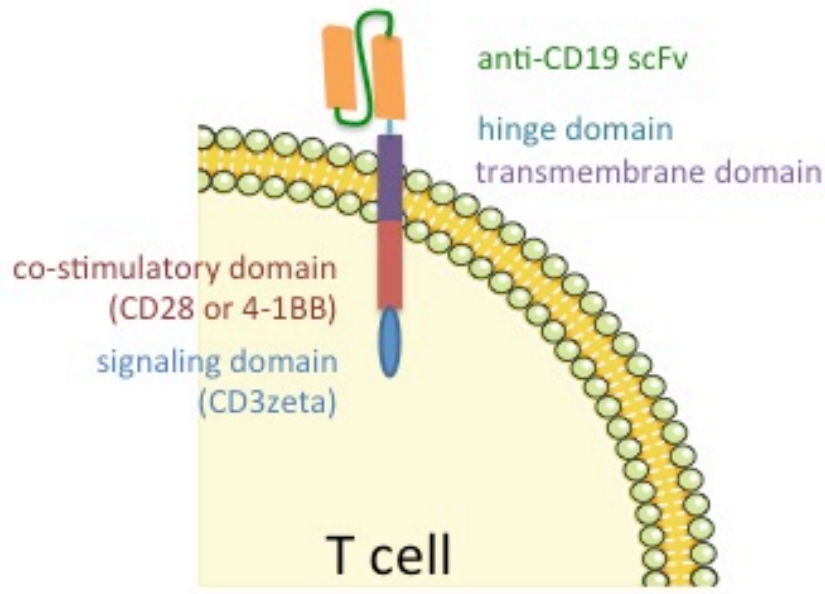

FIGURE 5 


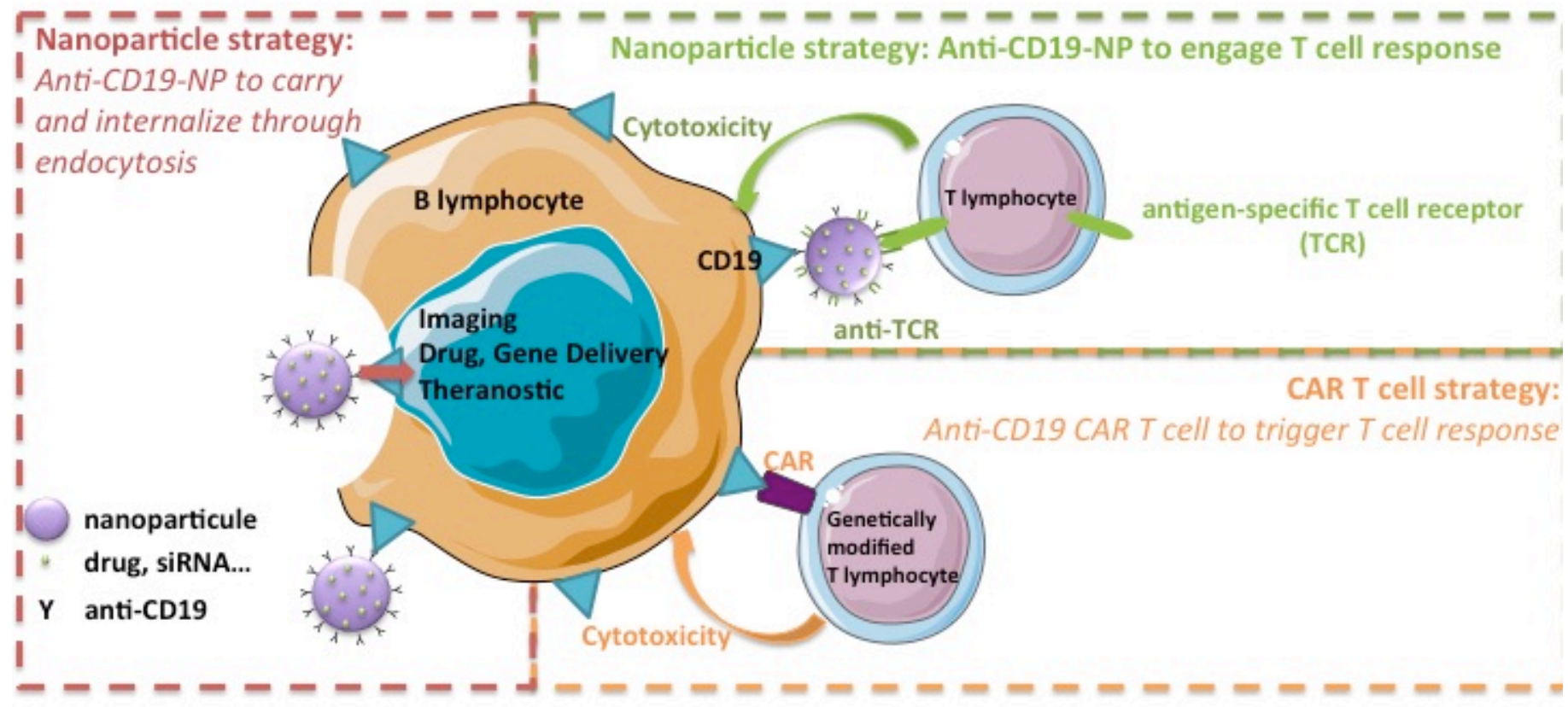

